\title{
PRAETORIAN PREFECTS AND OTHER HIGH-RANKING EQUESTRIANS
}

In the past, scholars have perceived a rise of the equites during the third century AD. ${ }^{1}$ However, this view is problematic in more than one way. Already in the high Principate-from the Flavian to the Antonine emperors-, the equestrian ordo was an even more heterogeneous group than the higher-ranking ordo senatorius. Within the political system, the most significant subset of equites contained those who served as equestrian officers in the army and senior civil administrators. ${ }^{2}$ Junior equites served as tribuni militum of legions and as praefecti of cohorts and cavalry units. Each year about 360 posts were available for senior officers of equestrian rank. These military officer-posts were a necessary hurdle for advancement to senior civil-administrative positions. ${ }^{3}$ Later, from the second century $\mathrm{AD}$, the post of advocatus fisci became an alternative precursor. ${ }^{4}$ Later in their careers, equites could serve as provincial procuratores, who were responsible for financial administration and sometimes military logistics, and supervised freedmen procurators who themselves administered imperial properties in their provinces. Furthermore, equites could be governors of minor provinces or imperial secretaries at court.

\footnotetext{
1 The notion of the rise of the equites was defined by Keyes (1915). Cf. Stein (1963), 444-459; Rémondon (1970), 100-101; Alföldy (1988), 193.

2 Millar (1992), 279-290, for instance, identifies three subsets within the ordo: (1) holders of the public horse, (2) jurors at Rome, and (3) military and civilian office-holders. For the purpose of this study I will focus only on the senior members of the last subset, as this group constituted, along with senior senators, the political elite of the Empire. It should be noted, however, that only a minority of the equites belonged to this subset of office-holders.

${ }^{3}$ Equestrian men usually started their career by filling a sequence of military posts (the so-called tres or quattuor militiae, depending on the number of positions). From the end of the Iulio-Claudian period the usual sequence of the tres militiae was praefectus cohortis-tribunus militum-praefectus alae. See Devijver (1989), 16-28; 56-72; and Dobson (1979).

4 The advocati fisci, employed by Hadrianus (HA, Vita Hadr. 20, 6), represented the fiscus (imperial treasury) in court (cf. for instance Digesta $28,4,3$ ) and apparently acted as legal authorities. On the advocatus fisci, see also Crook (1995), 52-53.
} 
Exceptionally successful equites could eventually reach the high prefectures which formed the zenith of the equestrian career: the praefectura annonae, the praefectura Aegypti or even the praefectura praetorio. In due course, the senior equestrian posts were qualified hierarchically by salary level; in that way an equestrian career developed by analogy with the senatorial cursus honorum. ${ }^{5}$ The equestrian career pattern, however, was never as strict as the senatorial one.

In the high Principate, most of the equestrians were landed gentry, but a minority consisted of ranking soldiers who had acquired equestrian status after holding the post of primuspilus (senior centurion of a legion). Because the ordo equester was more accessible to newcomers than the ordo senatorius, the equestrian order included far more members than the senatorial. ${ }^{6}$ And just as entry into the equestrian order was a personal honor bestowed by the emperor and not hereditary, so also ambitious equites who caught the attention of the emperor or one of his advisers could be promoted, or have their sons promoted, to senatorial rank through adlectio. By this process, the number of homines novi within the senate steadily increased during the first and second centuries AD. ${ }^{7}$

The heterogeneous character of the ordo equester in imperial times also emerges in the way the ordo has been dealt with in scholarly discussion: much effort has been made to collect the scattered evidence, which has led to a number of works that treat certain aspects of the equestrian career and the ordo equester, but books on the order as a whole are rare and have not been written recently. ${ }^{8}$ Besides the inherently heterogeneous charac-

${ }^{5}$ Salary levels of 60,000 (sexagenarii), 100,000 (centenarii), 200,000 (ducenarii), and 300,000 (trecenarii) HS were the basis of distinctions. Career inscriptions of equites use these descriptions as titles.

${ }^{6}$ Strabo, Geographica 3, 5, 3; 5, 1, 7, informs us that under Augustus 500 equites lived in Gades (Spain) and Patavium (Italy) respectively. According to Heil (2008b), 743, each generation of equites contained about 20,000 equites against circa 600 senators. Although these numbers may have changed after the Augustan era, the ratio of equites to senators will probably have remained fairly constant in the high Principate.

7 See most recently Heil (2008b), 740-744, on the development of the equester ordo in the first and second centuries.

8 The syntheses of Keyes (1915) and Stein (1927, second edition 1963) are outdated, but have not been replaced by more modern works. The amount of prosopographical research on specific aspects of the equestrian career is immense. See, for example, Pflaum (1950); id. (1960-1961); Devijver (1976-2001); id. (1989); id. (1992). Demougin (1988) focuses on the Iulio-Claudian period only. Demougin-Devijver-RaepsaetCharlier (1999) collects articles focusing on aspects of the order throughout several centuries, but does not amount to a history of the order as a whole either. Some articles sketch the broader outlines of the order and its role in imperial administration. See, for instance, 
ter of the order and the scattered evidence-which becomes ever more scanty in the course of the third century-there is another complicating factor: the equester ordo of the high Principate was a completely different group of people than the equestrian order of the late third century.

Hence, instead of speaking of a rise of the equites in general, it is better to first sort out in detail which equestrians saw their power increase in the very top of Roman imperial administration, where status and power had been steadily highest. Therefore, this chapter will start by focusing on the increasing authority that high-ranking equestrians acquired in the third century. For the sake of clarity this discussion is divided into three categories: (1) equites as provincial governors, (2) equites involved in warfare and military logistics, and (3) equites as imperial secretaries. Thereupon, I will briefly discuss whether the growing power had consequences for the status of those high-ranking equestrians involved. In the second part of this chapter, a case study on the praetorian prefects in the third century serves to further display and illustrate the developing position of (at least some of the) high equestrians in this period. As will become clear, the changing position of high-ranking equestrians as a group cannot be dissociated from their changing composition between AD 193 and 284 .

\subsection{The Increasing Responsibilities of \\ High Equestrians in Imperial Administration}

\section{Equites as Provincial Governors}

When Septimius Severus incorporated the northern part of Mesopotamia and organized it as a Roman province in the 190s, the emperor appointed an equestrian praefectus to govern the area. ${ }^{9}$ In itself this was not a novelty. From the early Principate onward, a number of provinces were put in the hands of equestrian governors. ${ }^{10}$ The province of Egypt,

Saller (1980); Alföldy (1981); Brunt (1983). For a recent discussion, see Heil (2008b), with further references to previous studies at $738-740$.

${ }^{9}$ On the prefects of Mesopotamia in the third century, see Magioncalda (1982).

10 Alpes Maritimae, Alpes Cottiae, and Alpes Poeninae, tree small provinces straddling the Alps, for instance, were governed by equestrians, as well as Mauretania Caesariensis and Mauretania Tingitana from the province's division in the first century. Raetia, Noricum, and Thracia were originally also governed by equestrian procuratores Augusti, but eventually transferred to senatorial legati Augusti pro praetore. On the names and ranks of the governors of these provinces and for further references, see Thomasson (1972-1990), vol. I, 63-68 (Alpes); 77-86 (Raetia and Noricum); 161-178 (Thracia); 409-418 (Mauretaniae). From time to time, Judaea/Syria Palaestina was of course also 
run by an equestrian praefectus, was of course the most renowned example and it paralleled Mesopotamia as it was the only other equestriangoverned province with legions stationed in it. ${ }^{11}$

Furthermore, from the Severan era onward, the number of cases in which senatorial governors were replaced by equestrian agentes vice praesidis increased. This trend continued and even intensified from 240 onward. The fact that agens $v$ (ice) $p$ (raesidis) was soon abbreviated as a.v.p. in inscriptions indicates that the Empire's inhabitants 'rapidly became familiar enough with the phenomenon. ${ }^{12}$ Equestrians had replaced senatorial governors in the first and second centuries as well, but only in exceptional cases, when a governor had died or had been dismissed. Those appointments had been temporary and lasted only until a new senatorial governor had been selected. Yet from the reign of Severus Alexander some areas, for instance Dacia, were so frequently governed by equestrian agentes vice praesidis that it is unlikely that all these men were appointed only as interim governors. The high number of agentes vice praesidis suggests that the practice lost its improvised character and that the emperors used these appointments as a way to assign certain provinces to equestrian governors without formally adjusting the institutions of provincial administration.

Illustrative of this development is the career of Timesitheus. Before he became praetorian prefect under Gordianus III, Timesitheus had gone through a long career with several appointments as deputy governor (agens vice). Under Elagabalus Timesitheus was procurator in Arabia serving as an agens vice praesidis twice. Under Severus Alexander he was agens vice praesidis of the province of Germania Inferior, while simultaneously holding a position as agens vice procuratoris of the imperial properties in Belgica, Germania Superior and Germania Inferior. That the emperor was fighting Germanic invaders in the Rhine area in those years (AD 233/234) bolsters the significance of these positions. Pflaum argued

governed by equestrians, but this province is notorious as it shifted from being ruled by friendly kings to being ruled by Romans, and as it was strongly dominated by the governor of Syria. On Judaea, see Goodman (2000).

11 The literature on the administration of Egypt is immense. On the praefecti governing Egypt, see, for example, Reinmuth (1935); Stein (1950); Brunt (1975); Bastianini (1988); Bureth (1988); Jördens (2009); on Roman imperial power in Egypt in the third century, see De Jong (2006).

12 Peachin (1996), 156. Cf. CIL 3.1625 (Dacia), which can be dated in the reign of Septimius Severus, with the description agens v(ice) p(raesidis), and CIL $3.1464=I L S$ 1370 (Dacia), probably to be dated in Caracalla's reign, which yields the abbreviation a.v.p. 
that appointing Timesitheus agens vice procuratoris was just a necessary step to allow him to also become deputy governor of Germania Inferior and thus commander of the two legions stationed in this province. ${ }^{13}$ But moreover, Timesitheus' combining the governorship with his position as procurator of the Rhineland's imperial domains-a position normally assigned to freedman procuratores-simplified logistics: the dual authority enabled Timesitheus both to collect the resources required for wars against the invading tribes and to direct the battles. ${ }^{14}$ According to Pflaum, Timesitheus was subsequently procurator of the imperial properties and simultaneously agens vice praesidis in Bithynia et Pontus, including Paphlagonia, and finally procurator and vice proconsulis in the province of Asia under Maximinus Thrax. In Asia, Timesitheus may have replaced proconsul Valerius Messalla Apollinaris (see Chapter 2), the father of Valerius Maximus, who has been identified as one of the vigintiviri of the year 238. If true, this may have indicated that the policy of replacing senatorial governors had negatively affected the position of the senatorial elite discussed in Chapter 2. The lacunae in the fasti of the provincial governors, however, do not allow us to test this hypothesis with a convincing amount of evidence. Being appointed as four different agentes vice, Timesitheus may not have been representative of a typical eques replacing senatorial governors, as he obviously was an exceptionally successful member of the equestrian order. Yet Timesitheus' career indicates how continuous accumulation of basically equestrian positions could consolidate a senatorial governor's level of power (or even higher) for an eques. ${ }^{15}$

Under Gallienus in the 26os, the process of replacing senatorial governors by equestrian men continued and seems to have extended further: the available evidence reveals that there were relatively more agentes vice praesidis in comparison with the late Severan era. From Gallienus' reign onward some provinces, like Arabia, Macedonia and Numidia,

${ }^{13}$ For an overview of Timesitheus' career, see Pflaum (1960-1961), vol. 2, 816, no. 317.

14 On freedmen as procuratores of imperial domains, see Weaver (1972), 267-281.

15 Petersen (1955), 47, who claims that the cumulation of vicariates in Timesitheus' career does not indicate imperial policy, but that he was entrusted with many vicariates because he was closely related to Gordianus III, obviously did not take into account that these replacements were held under Gordianus III's predecessors, Elagabalus, Severus Alexander and Maximinus Thrax. Other examples of equites who functioned vice praesidis can be found in the lists of Pflaum (1950), 134-136; Rémy (1976), 466-470; Peachin (1996), appendix 4, 229-238. See also Malcus (1969), 217-223, on equestrian agentes vice praesides, and most recently Heil (2008b), 750-751, for further references and examples of the trend. 
were almost continuously governed by equestrian men, who were still called (procuratores) agens vice praesidis and thus officially still acted as deputies of senatorial governors. ${ }^{16}$ Yet the change was not executed systematically; senatorial governors were not ousted by equites everywhere. Even after 260, senatorial men crop up among provincial governors, especially in senatorial consular provinces which were not struck by long-term crisis like Africa and Asia, but also in imperial provinces such as Hispania Tarraconensis and areas in the Balkans, as has been discussed in Chapter $2 .{ }^{17}$

The emperors after Gallienus did not reverse the process either. On the contrary, they even enlarged the proportion of provinces governed by equestrians. ${ }^{18}$ The fact that most of these emperors originated themselves from the ordo equester, as discussed in Chapter 1, must have boosted this trend. Eventually, the agentes vice praesidis became so common that they were simply referred to as praesides. In areas which experienced frequent internal or external military crises, the equestrian praesides probably carried out mainly civil-administrative and judicial tasks; the military responsibilities of these regions went increasingly into the hands of duces and praepositi, as will be discussed below. In other regions, however, maintaining order may have belonged within the range of duties of the praeses. Zosimus tells of bands of robbers led by a certain Lydius the Isaurian, who were active in Lycia et Pamphylia during Probus' reign. The emperor sent as praeses to this area eques Terentius Marcianus. There is a fair chance that he was the Roman general, referred to by Zosimus ( 1 ,

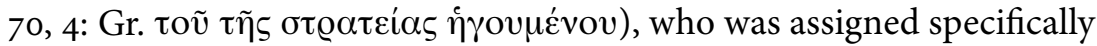
to this problem. The possibility that Marcianus served as military officer in the area, before he was promoted to the position of praeses, cannot be excluded. ${ }^{19}$

16 The province of Numidia, created under Septimius Severus, was initially governed by a senatorial legatus pro praetore. He was replaced by an equestrian governor under Gallienus. On the provincial administration in Numidia from Septimius Severus to Gallienus, see Le Glay (1991).

${ }_{17}$ On the process in the 260 s and for examples and further references, see Heil (2008b), 757-758.

${ }^{18}$ Kreucher (2003), 202-212, describes the situation at the end of the period under discussion. The table at p. 211, clearly shows that equestrian governors prevailed under Probus, but that senators were not entirely displaced as governors. Cf. Glas-Hartmann (2008), 669.

19 On Lydius, see Zosimus 1, 69-70; On Terentius Marcianus, see AE 1995, 1541 (Pisidia). On Lydius and Terentius Marcianus' role in Lycia et Pamphylia, see Kreucher (2003), 150-155, with further references. 
Very little can be said about the origin and previous careers of the agentes vice praesidis and praesides, as the rise of these men coincided with a numerical and qualitative decline of extensive career inscriptions. Their names indicate that their families did not belong to any groups which had been involved very long in imperial administration, and that some of these men even belonged to families which had only been granted Roman citizenship in the course of the third century. Some of them were social upstarts who had risen from the corps of officers, like Aelius Aelianus, praefectus legionis under Gallienus, who became praeses of Mauretania Caesariensis in the $270{ }^{20} .^{20}$ Aurelius Marcianus, dux under Gallienus, who fought the Goths in the Balkans and became praeses Dalmatiae under Probus, is another example. ${ }^{21}$ In some cases, the appointed praeses was already present in the area, serving as an officer before being promoted. ${ }^{22}$ Experience in the military and logistic sphere was apparently a good reason to appoint a man praeses, yet there may also have been equites with a civil career who were made praesides, especially if immediate availability was a decisive factor in appointments. The evidence is just too fragmentary to exclude men with financial or legal backgrounds, or to draw more specific conclusions on the previous careers of the praesides in general.

By the end of our period, in the 270 s and early 280 s, equestrians were administering a considerable number of provinces. This development described above certainly bolstered the status of those equites who

${ }^{20}$ If the Aelius Aelianus mentioned in CIL 3.3529 (Pannonia Inferior) and $A E$ 1965, 9 (Pannonia Inferior), is indeed identical with the one mentioned in CIL 8.21486 = ILS 4495 (Mauretania Caesariensis), as has been assumed in Dobson (1978), 312, no. 220. Cf. PLRE I, Aelianus 8 and 10; Pflaum (1960-1961), vol. 2, 948-952, no. 357. On Aelius Aelianus, see also Chapter 4, section 4.2.

${ }^{21}$ If the Marcianus praised in $A E 1965,114$ (Thracia) and mentioned in HA, Vita Gall. 6,1 , is identical with the man mentioned in CIL 3.8707 (Dalmatia). See PLRE I, Marcianus 2 and 18. Dobson (1978), 320, no. 230, discusses an Aurelius Marcianus, referred to in CIL 6.2487 (Roma), who was primuspilus cohortis III Pretoria. He may have been identical with the Marcianus, dux under Gallienus and praeses in Dalmatia, as well. Although Dobson assumes that the inscription dates to the third century, he does not mention the possibility that these men may have been identical. For further examples of men who had risen from military ranks and eventually became praeses, see Heil (2008b), 759, note 89. On Marcianus, see also Chapter 4 below, section 4.2.

${ }^{22}$ For example Statilius Ammianus (CIL 3.90; IGRR 3.1287 (Arabia); PLRE I, Ammianus 5), who was praefectus alae circa 253/256 and agens vice praesidis Arabiae in 262 / 263 . Another example is M. Aurelius Valentinus in Macedonia ( $A E$ 1900, 169, Macedonia; PLRE I, Valentinus 8), who was tribunus and agens vice praesidis in 276 . Cf. Heil (2008b), 759. As said above, this may also have been the case with Terentius Marcianus in Lycia et Pamphylia under Probus. 
were involved in provincial administration: their tasks were no longer restricted to specific regions or traditional tasks, for they could now be deployed anywhere the emperor needed them. Furthermore, the possibilities for them to become provincial governors increased, whereby they gained influence in the civil-administrative sphere.

\section{Equites Involved in Warfare and Military Logistics}

Septimius Severus not only assigned the province of Mesopotamia to an equestrian governor, but put the newly created legiones Parthicae under the command of equestrian praefecti as well. ${ }^{23}$ Moreover, the trend toward substituting senators with equites, which could be detected among the third-century provincial governors, also surfaces among military officers. The command of vexillationes and other temporary army units-the deployment of which grew significantly in the third century, as flexibility became more crucial and the complete legions were mobilized less often -went increasingly into the hands of capable equestrian duces or praepositi. ${ }^{24}$ Septimius Severus still assigned most of these temporary units to senatorial commanders, albeit often homines novi and thus first generation senators. The expeditionary forces of Caracalla and Severus Alexander, however, included significantly fewer senatorial commanders, and under Gallienus practically all high commands went to equestrians, as will be discussed in Chapter 4 .

Yet until the 250s, senators were still appointed to relevant military posts. Great regional commands, which were created from the $240 \mathrm{~s}$ onward to defend the borders and maintain order in specific areas, went to both senators and equites. For example, Priscus held such a supra-provincial command in the East under Philippus Arabs, while maintaining equestrian status, while Cornelius Octavianus, who was initially equestrian praeses in Mauretania Caesariensis, was promoted to the position of dux per Africam Numidiam Mauretaniamque to defend the African limes against invading tribes in the 250s. On the other hand, the fact that Decius, who had gone through a traditional senatorial career, commanded the united troops of Moesia and Pannonia under Philippus

${ }^{23}$ Smith (1972). On the increasing number and significance of equestrian positions under Septimius Severus and his successors, see also Coriat (1978); Birley (1988), 195196. Cf. Campbell (2005a), 12-13, who points out that two of the newly created legions were stationed in Mesopotamia, which had an equestrian governor, 'and a senator could not be asked to serve under an eques.

${ }^{24}$ On vexillationes, see Saxer (1967); on duces and praepositi, see Smith (1979). 
Arabs shows that senators still received such military assignments in the 240 as well. To what extent such commands included non-military tasks remains unclear. ${ }^{25}$

By the sole reign of Gallienus, senatorial tribuni militum were no longer attested and the practice of replacing senatorial legati legionis with equestrian praefecti legionis had become widespread. These equestrian legionary commanders were originally called praefecti legionis agentes vice legati and thus presented as deputies of senatorial commanders. Later, the title was abbreviated to praefecti (castrorum) legionis. ${ }^{26}$ The development seems to have been analogous to the multiplication of agentes vice praesidis, who were eventually simply called praesides. High military commands in regions continuously struck by internal or external military crises went by then only to equestrians with considerable military or logistical experience, who then often bore the title dux. Whereas the supra-provincial commanders appointed in the 240 os and 250 s may have had civil-administrative duties as well, these duces do not seem to have been responsible for non-military matters within the provinces

${ }^{25}$ Cf. Glas-Hartmann (2008), 654, who claim that such supra-provincial commands included both civil and military authorities and were initially given mainly to senators. However, in Decius' case it is unclear whether he also acted as governor of the Moesian and Pannonian provinces. Zosimus 1, 21, 2, only refers to the command of the legions. On Decius' command in the Danube area, see also PIR ${ }^{2}$ M 520; Huttner (2008), 201202; Johne-Hartmann-Gerhardt (2008), 1162, with further references. The same lack of clarity applies to the exact range of duties of Decius' predecessor Ti. Cl. Marinus Pacatianus (PIR ${ }^{2} \mathrm{C} 930 ; \mathrm{cf}$. P 6). It has been assumed that he was the son of a senator, but his senatorial status has been disputed. On Pacatianus, see Huttner (2008), 199-200, and Glas-Hartmann (2008), 655, with additional references. For more information on Priscus' command in the East and further references, see PIR ${ }^{2} \mathrm{I} 488$; Körner (2002), 366367; Johne-Hartmann-Gerhardt (2008), 1178-1179. On M. Cornelius Octavianus, see $P_{I R}^{2}$ C 1408; Glas-Hartmann (2008), 658; Johne-Hartmann-Gerhardt (2008), 1139, with further references.

${ }^{26}$ For example P. Aelius Aelianus ( $A E$ 1965, 9; CIL 3.3529) praefectus legionis (agens vice legati) II Adiutricis; Valerius Marcellinus (CIL 3.3424 = ILS 545, Pannonia Inferior) praefectus legionis agens vice legati II Adiutricis; Aurelius Frontinus (CIL $3.3525=$ CIL $3.10492=$ ILS 2457) praefectus legionis, all in Pannonia Inferior under Gallienus; $\mathrm{Cl}$. Aurelius Superinus (CIL $3.4289=I L S 3656)$ praefectus legionis agens vice legati in Pannonia Superior under Claudius Gothicus; cf. Aurelius Montanus (CIL 3.14359, 27 = ILS 9268) vices agens legati legionis in Pannonia Superior, and Aelius Paternianus (CIL 3.3469) praefectus legionis agens vice legati in Pannonia Inferior in the early 280 os. Cf. Christol (1982), 147. The title praefectus legionis vice legati was first attested under Severus Alexander for a commander of Legio II Parthica called Licinius Hierocles (ILS 1356, Mauretania Caesariensis). On the praefecti legionis, see also Malcus (1969), 228230. 
assigned to them. ${ }^{27}$ Thus, in the 260 , senators no longer held high positions in the military bureaucracy. According to Aurelius Victor, the emperor Gallienus even issued an official edict forbidding senators to take military commands. ${ }^{28}$ The question whether there actually was such a decree has provoked extensive scholarly discussion. Indeed, military tribunates and legionary commands disappeared from senatorial career inscriptions, and senatorial governors of provinces with relevant troops or legions stationed in it had become rare from the 240 onwards, as observed in Chapter $2 .{ }^{29}$ Whether there actually was an edict or not,and in fact Aurelius Victor's statement is the only evidence for its existence-, the available sources indicate that at this point Gallienus rather formalized what had gradually become common practice than that he came up with deviant appointment policies and radical reforms. ${ }^{30}$

At other points, Gallienus' reorganizations of military structures seem to have been more radical. He created special military units, which were independent of the legions and directly linked to the emperor in person. These units could be moved around easily and could therefore be mobilized as an intervention force. The high percentage of cavalry guaranteed that this army could swiftly track down and destroy small looting groups or enemies who had dispersed for logistical reasons. Whether this army was a temporary unit which was made permanent, or a permanently available imperial expeditionary army, is unclear. Its command was held by a powerful equestrian commander, as Chapter 4 will discuss further. The vexillationes seem also to have attained permanent status by the reign of Gallienus. Due to continuous fighting, they were no longer called up ad hoc for specific purposes and then sent back to their original units, but served continuously in the new imperial reserve army on various fronts. ${ }^{31}$ Strategically important places, such as Milan and Aquileia in northern Italy, and towns in northern Gallia and the Danube area and even Asia Minor, were fortified and defended by new garrisons, whose soldiers were detached from various legions and put under the command of equestrian duces as well. All these measures amounted to a much more

27 On the duces under Gallienus and their responsibilities, see Chapter 4 of this study.

28 Aurelius Victor, Liber de Caesaribus, 33, 33-34; 37, 5-6.

29 This was first observed by Pflaum (1976). Cf. Christol (1986), 39-44; Heil (2008b), 754; Hekster (2008), 41, supplying further references and examples.

${ }^{30}$ Cosme (2007) summarizes the scholarly debate on the 'edict'.

${ }^{31}$ For example, L. Flavius Aper, who was praepositus (vexillationum) legionum $V$ Macedonicae et XIII Geminae Gallienarum ( $A E$ 1936, 53-54, 57, Pannonia Superior). Cf. Saxer (1967), 56-57. 
flexible system of defense, foreshadowing defense methods of the later Roman Empire. ${ }^{32}$

The continual internal and external threats also affected the position of equites in offices that oversaw military logistics, especially from the 250 onwards. How material resources were deployed to provision the Roman armies, in the form of taxes in money and kind, is a complex matter which is still subject to debate. One complicating factor is that the Roman Empire never developed a uniform and universally applied military supply system. ${ }^{33}$ Here, the subject can only be touched on briefly, focusing on the role of high equites within logistics and how thirdcentury events impacted their level of power.

One of the key figures in wartime logistics was the a rationibus (head of the central administration of the emperor's finances) who, after an emperor had decided to wage a war, handled the finances for the forthcoming campaign. A remarkable series of men with full military and civilian equestrian careers held the office of a rationibus, and several of them even ascended from below the equestrian order, from the rank of senior centurion. ${ }^{34}$ Furthermore, the office of the annonae helped to plan, organize, and supervise the collection and transportation of grain. Its equestrian praefectus presumably had to coordinate all relevant supply efforts with the a vehiculis or the praefecti vehiculorum, supervisors of the imperial posting-system and in charge of provincial roads. ${ }^{35}$ Army supply depended highly on requisitions. According to the Historia Augusta, Severus Alexander made such careful provision for the

32 De Blois (1976), 30-34; Simon (1980); Potter (2004), 257-258; Campbell (2005b), 115; Strobel (2007).

${ }_{33}$ On logistics in the Roman Empire and for further references, see Roth (1999) and Kehne (2007). On logistics and supply in the Republican era, see Erdkamp (1998).

${ }^{34}$ Millar (1992), 105-106, who points out that many of the a rationibus held procuratorships in Gallia before being a rationibus. Contrary to Eck (2000), 240, who includes the a rationibus among the officia Palatina, Millar explicitly distinguishes the post of $a$ rationibus from the secretarial posts on the grounds that the a rationibus did not work closely with the emperor, did not (usually) attend him or travel with him, or act as the emperor's adviser, but instead operated independently of the emperor and at a distance from him.

${ }^{35}$ The praefectus vehiculorum was head of the cursus publicus, arranging the transmission of messages or transportation on behalf of public institutions (officials, military, and goods). See Kolb (2000), 159-166. In due course, the administration of the annona militaris, a special tax presumably raised by Septimius Severus for the benefit of the army, was transferred to the praetorian prefects. Most scholars, however, accept that this transfer took place after AD 284. See also below (section 3.3), on this matter, with further references. 
soldiers that they received supplies at each halting-place. The text even refers to a proclamation which was allegedly issued by Severus Alexander, in which the emperor demanded that his army be supplied along the line as it marched. Although the Vita Severi Alexandri probably reflects what was considered to be proper imperial behavior in the late fourth century, it is not unlikely that such provisions were made by third-century emperors:

He always kept secret the plan for a campaign, but announced openly the length of each day's march; and he would even issue a proclamation two months beforehand, in which was written, "On such and such a day, and at such and such an hour, I shall depart from the city, and if the gods so will, I shall tarry at the first halting-place." Then were listed in order all the halting-places, next the camping-stations, and next the places where provisions were to be found, for the whole length of the march as far as the boundaries of the barbarians' country. ${ }^{36}$

Other responsibilites in military logistics went to the ab epistulis (head of the office controlling the emperor's correspondence), who sent out demands to allies for supplies and recommended qualified officers or prefects for special posts, like the praepositus annonae expeditionis. ${ }^{37}$ Such extraordinary commands remained limited in time and restricted to a specific task. Tiberius Claudius Candidus, for example, functioned as praepositus copiarum in the second Marcomannic war of Marcus Aurelius. ${ }^{38}$ One Rossius Vitulus was praepositus annonae during Septimius Severus' expedition to Rome, procurator arcae expeditionalis (dispensing the expeditionary treasure chest) in the war against Niger, and subsequently appointed as procurator annonae for the expeditio Gallica in $196 .{ }^{39}$ At the corps level, primipili of the expeditionary forces were responsible for army supplies. Primipili were also assigned to logistical duties like supervising the overseas supply lines during wars, in important harbors like Aquileia. ${ }^{40}$

Several third-century careers demonstrate the significant role that equites involved in logistics could play. Some of these men eventually reached the highest equestrian prefectures. An inscription from Rome

\footnotetext{
${ }^{36}$ HA, Vita Sev. Alex. 45, 2; cf. 47, 1. On the Vita Severi Alexandri, cf. BertrandDagenbach (1990). On imperial travel in general, see further Halfmann (1986).

37 On the role of the ab epistulis in logistics, see Kehne (2007), 330.

${ }^{38}$ CIL $2.4114=I L S 1140$ (Hispania Citerior).

${ }^{39} A E$ 1914, $248=A E$ 2002, $54=$ IlAfr 455 (Africa Proconsularis). On M. Rossius Vitulus, see PIR ${ }^{2}$ R 102; Pflaum (1960-1961), vol. 3, 593-598, no. 224; Devijver (19762001), vol. 2, R 11, with further references.

${ }^{40}$ Cf. Kehne (2007), 331.
} 
dated in the Severan era offers a fine example of an anonymous man whose career included almost all relevant logistic positions: after having been tribunus militum and praefectus classis, this man continued his career with procurational posts, procurator ad alimenta being the first. At the end of his career, he was subsequently ab epistulis, a libellis, a rationibus, and finally praefectus annonae. It has even been suggested that this man was identical with Severus' powerful praetorian prefect Fulvius Plautianus, but this hypothesis has been refuted ${ }^{41}$ Yet it is striking that the alternative theory requires that Plautianus' name was erased from an inscription from Tripolitana, in which case he would have been praefectus vehiculorum prior to his praetorian prefecture, a position which the eventual emperor Macrinus also occupied at one point. ${ }^{42}$ Another eques involved in logistics who reached a high prefecture was Baebius Aurelius Iuncinus, who was procurator ad annonam Ostiis and praefectus vehiculorum twice, and finally became praefectus Aegypti under Caracalla. ${ }^{43}$ Perhaps Aurelius Iulianus can also be added, if the $a$ rationibus et a memoria mentioned in an inscription from Latium is identical with the praefectus praetorio mentioned in an inscription from Venetia et Histria. $^{44}$

The career of Fulvius Macrianus maior demonstrates how a convenient combination of logistically relevant posts could even create the opportunity to claim imperial power. Macrianus became a rationibus in Egypt under Valerianus. Next, he accompanied this emperor on his Persian campaign and became responsible for the organization of money and supplies for the army in the East during this expedition as procurator

${ }^{41}$ CIL $6.41277=14.4468-4470=I L S 9501=A E$ 1960, 163-164 (Roma); see Devijver (1976-2001), vol. 2, inc. 255.

$42 A E$ 1931, $2=I R T 572$ (Tripolitana). See DNP, Band 6, s.v. Fulvius II.10. Pflaum (1960-1961), vol. 2, 643-644, no. 238, doubted whether this inscription referred to Plautianus. On Macrinus as praefectus vehiculorum, see Dio 79, 11, 3.

${ }^{43}$ On L. Baebius Aurelius Iuncinus see PIR ${ }^{2}$ B 13; CIL 10.7580 = ILS 1358 (Sardinia); P. Oxy. 1408; P. Giss. 40; Pflaum (1960-1961), vol. 2, 678-683, no. 251; Bureth (1988), 491; Bastianini (1988), 512. Although the position procurator ad annonam Ostiis was a minor procuratorship, its relevance may have increased in certain periods. Iulia Domna's brother-in-law, Iulius Avitus Alexianus, for instance, was procurator ad annonam Ostiis in 193, which may have been useful for Severus as he marched on Rome. Cf. Birley (2005), 226.

${ }^{44}$ On M. Aurelius Iulianus: CIL 14.2463 = CIL 6.1596 (Castrimoenium, Italy); CIL $5.4323=I L S 1333$ (Brixia, Italy). The praetorian prefect mentioned in the latter inscription was perhaps the same Iulianus who is mentioned as praefectus praetorio in Cod. Iust. $7,33,1$, which dates from the joint reign of Severus and Caracalla. 
arcae et praepositus annonae in $259 / 260 .{ }^{45}$ After Valerianus had been captured, Ballista offered Macrianus the imperial throne, but Macrianus allegedly refused and suggested that his sons, Macrianus minor and Quietus, would become joint emperors. They were proclaimed not much later, with Macrianus maior's control over the imperial treasure and the army supplies in the East-essential sources in wartime-as the principal base of their power. ${ }^{46}$

A comparable case emerges in the career of Mussius Aemilianus. After having gone through the quattuor militiarum, he was appointed praefectus vehiculorum of the three Gallic provinces during the reign of Philippus Arabs. ${ }^{47}$ Then, he held the position of procurator of the three Egyptian ports (Alexandria, Pelusium and Paraetonium) and subsequently of the two ports in Ostia, still under Philippus. Under Valerianus, Mussius Aemilianus governed Egypt, first as deputy governor (agens vice praefecti) with two correctores to assist him, and later as praefectus Aegypti. The fact that he is referred to as $d u x$ by the Historia Augusta may indicate that his responsibilities were restricted to the military when he was agens vice praefecti, while the correctores carried out the civil-administrative tasks. ${ }^{48}$ As praefectus, Aemilianus supported the rival emperors Macrianus and Quietus. ${ }^{49}$ After their deaths, he was proclaimed emperor himself in 261 , but soon overthrown by $d u x$ Aurelius Theodotus and executed by Gallienus. ${ }^{50}$ Mussius Aemilianus was thus appointed to positions in which he was responsible for, and had access to, important (food) supplies in both Egypt and Italy. According to Pflaum, Aemilianus' rapid pro-

45 Eusebius, Historia Ecclesiastica 7, 10, 5-6; Petrus Patricius, Continuator Dio, Ex-

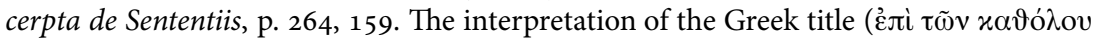

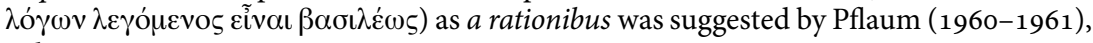
vol. 2, 928-933, no. 350 .

46 According to Eusebius, Historia Ecclesiastica 7, 10, 8, Macrianus refused because his body was deformed; Zonaras 12, 24, and Petrus Patricius, Excerpta de Sententiis, p. 264, 159, report that he was lame in one leg. According to HA, Vita Tyr. Trig. 12, 7, he declined because of his old age and his long retirement from the military. HA, Vita Gall. 1, 3; Vita Tyr. Trig. 12, 12, reports that Macrianus shared the emperorship with his sons, but this seems incorrect.

47 See CIL $14.170=$ ILS 1433 (Ostia, Italy) for his early career; cf. PIR ${ }^{2}$ M 757; PLRE I, Aemilianus 6.

${ }^{48}$ In HA, Vita Trig. Tyr. 22, 3, Mussius Aemilianus is called $d u x$. According to PIR ${ }^{2}$ $\mathrm{M} 757$, these correctores held a superior rank.

${ }^{49}$ Mussius Aemilianus' support appears from the fact that the coins of Macrianus and Quietus were struck at Alexandria. Cf. PLRE I, Aemilianus 6.

50 HA, Vita Gall. 4, 1-2; 5, 6; Vita Trig. Tyr. 22, 4; 22, 8; 26, 4; Epitome de Caesaribus 32,4 . 
motion indicates that he was favored by the emperor Philippus Arabs. ${ }^{51}$ Philippus may also have been a specialist in military logistics: Zosimus reports that during Gordianus' Persian campaign in Mesopotamia in 242, Philippus commanded the ships that had to bring supplies to the emperor's army over the Euphrates. ${ }^{52}$

Military cadre personnel, i.e. primipili, centurions, tribuni and praefecti, were ever more involved in military logistics as well: they carried out requisitions to feed the armies and continue the wars. ${ }^{53}$ They were also increasingly mobilized by civilians to communicate messages to the emperor and his entourage. Military cadre people communicated the complaints about Cassius Dio's harsh policy as governor of a Pannonian province to the praetorian guard, which forced Severus Alexander to keep Dio out of Rome in 229, when he was consul ordinarius iterum with the emperor as his colleague. ${ }^{54}$ As has been discussed in Chapter 1, under Gordianus III and Philippus Arabs, villagers of Skaptopara in Thracia and Aragua in Asia Minor respectively, sent military men instead of an orator to the emperor to bring him petitions-a sign that by the end of the 230s, the influence of intellectuals had decreased, as is discussed in the next section.

\section{Equites as Imperial Secretaries}

Moreover, as regards legal cases, letters and decrees of the cities, petitions of individuals and whatever else concerns the administration of the Empire, you should have helpers and assistants from the equites. ${ }^{55}$

The advice which Cassius Dio puts into the mouth of Maecenas as he addresses the emperor Augustus relates to the author's own time and reflects yet another equestrian office close to the center of power: acting as imperial secretaries. In the early Principate, secretarial posts had been filled by imperial liberti, but these duties had been gradually transferred to equestrian men which are distinguished into two groups by Millar: (1) intellectuals, orators and jurists who did not rise through any recognizable career path but entered the imperial entourage directly, and (2) men who were promoted to the imperial secretaries after a career of three equestrian military posts, followed by procurational positions.

51 Pflaum (1960-1961), vol. 2, 926-927.

52 Zosimus 1, 18, 3. Cf. De Blois (2001), 140-141.

53 Dobson (1974), 432; cf. Dobson (2000), 142; 151-152.

54 On this, see De Blois (2001), 150, with further references.

55 Dio 52, 33, 5. Translation: Millar (1992), 105. 
Millar emphasizes that the liberti were not in the first instance replaced by equestrian civil servants, but by intellectuals from the Greek and later the Latin world.$^{56} \mathrm{~A}$ good example of this trend is the author Suetonius, who after being selected by Traianus to sit on the juries of equites who sat in Rome, subsequently was a studiis and a bibliothecis, perhaps still under Traianus, and later became Hadrianus' ab epistulis. ${ }^{57}$ For such intellectuals their scholarly reputation was the main recommendation for the imperial posts.

In the course of the second and the early third century, Greek sophists gained rising prominence at the imperial court, and the function of $a b$ epistulis Graecis turned out to be one of the chief posts open to them. Of the four rhetors in this post whose lives Philostratus described, two belong to the period under discussion: Aelius Antipater of Hierapolis (Phrygia) and Aspasius of Ravenna (Italy). ${ }^{58}$ Antipater was not only appointed ab epistulis Graecis by Septimius Severus, but also tutored Caracalla and Geta, thus evidently acquiring prestige in the emperor's entourage and accompanying the imperial family on their journeys. Having also written a huge number of orations and a biography of Septimius Severus, Antipater attained senatorial rank and was appointed governor of Bithynia, but was eventually removed for excessive harshness. He allegedly starved himself to death after the murder of Geta. ${ }^{59}$ Aspasius, who despite his Italian origins gained fame as a Greek orator, was ab epistulis under one of the Severi and in that capacity accompanied the emperor to various parts of the Empire. ${ }^{60}$

${ }^{56}$ Millar (1992), 89, points out that some secretarial posts had been held by Greeks of equestrian rank as early as Claudius' reign. Suetonius, Dom., 7, 2, reports that Domitianus 'shared certain of the chief officia between libertini and equites Romani' (translation Millar). HA, Vita Hadr. 22, 8, is thus incorrect in stating that Hadrianus was the first emperor to have equites as ab epistulis and a libellis.

57 AE 1953, 73 (Africa Proconsularis). Cf. Millar (1992), 90. On Suetonius, see also Baldwin (1983) and Wallace-Hadrill (1984).

58 The other two were Alexander from Seleucia (Philostratus, Vitae Sophistarum 2, 5), ab epistulis of Marcus Aurelius between 169 and 175; and Hadrianus of Tyre (Philostratus, Vitae Sophistarum 2, 10), who was nominated ab epistulis on his deathbed by Commodus. Cf. Millar (1992), 91-92.

59 On Aelius Antipater, see Philostratus, Vitae Sophistarum 2, 24-26; IEph $2026=$ Oliver (1989), no. 244, with commentary on 471-474. Cf. Bowersock (1969), 53; 55-57; Millar (1992), 92-93; Potter (2004), 78.

60 On Aspasius, see Philostratus, Vitae Sophistarum 2, 33. Potter (2004), 78, assumes he was appointed ab epistulis Graecis sometime between AD 211 and 216. Cf. Bowersock (1969), 56; 92; Millar (1992), 93. Peachin and Preuss (1997), 189-191, suggest that (Aspasius) Paternus, praefectus urbi 264-266, descended from Aspasius of Ravenna. 
Another group came to the fore from the reign of Marcus Aurelius onward: the jurists. The persons who in the second and third centuries entered the emperor's service as jurists did so as a libellis (in charge of the processing of petitions) or as consilarii (advisers on the consilium). The appearance of the legally-qualified a libellis is-like the emergence of iudices vice Caesaris from the reign of Septimius Severus onward-yet another clear sign of the bulk of legal business with which the emperor had to deal by then. ${ }^{61}$ The earliest example of a man who owed his career to his standing as a lawyer was Aurelius Papirius Dionysius, who was $a$ libellis and a cognitionibus (in charge of the emperor's court of law, contributing to judicial investigations), before he reached the high equestrian prefectures of the annona and subsequently of Egypt. ${ }^{62}$ Dionysius started his career under Marcus Aurelius and became part of the consilium. ${ }^{63}$

Well before the Severan period lawyers were co-opted directly into the emperor's consilium, under Severan administration learned jurists rose to the top, with Papinianus, Ulpianus and Iulius Paulus being the most striking examples. ${ }^{64}$ Aemilius Papinianus evidently was a member of a praetorian prefect's consilium and had been advocatus fisci before he became a libellis in the early part of Septimius Severus' reign. Between 205 and 211 he served as praetorian prefect. ${ }^{65}$ Domitius Ulpianus of Tyre (Syria) may have served as assessor on the court of a praetor in Rome in the early reign of Severus. Late sources record that he was an apprentice of the praetorian prefect Papinianus and a member of his consilium, and that he was at some stage a libellis. Although the sources are not the most reliable, Honoré has shown that Ulpianus' style indeed corresponds

61 On the libelli, see Millar (1992), 240-252.

62 The a cognitionibus personally attended the emperor and accompanied him on his journeys. Millar (1992), 106-107, points at an a cognitionibus who was with Severus in Asia Minor in 202, one who was with Caracalla in Rome and Gallia or Germania, and Cledonius, a cognitionibus of Valerianus, who was with him when he was captured by Shapur. Millar adds that those a cognitionibus from the Severan period of whom we have information, seem to have had normal equestrian careers.

63 On Aurelius Papirius Dionysius, see IGRR I, no. 135; Dio 73, 13-14; PIR ${ }^{2}$ A 1567; Pflaum (1960-1961), vol. 1, 472-476, no. 181; Millar (1992), 94.

64 On direct co-option of lawyers into the consilium, see Digesta 27, 1, 30 (Papinianus). On the lawyers under the Severan emperors, see Millar (1992), 94-97; Honoré (1994), 19-32; De Blois (2001), 138-141.

65 On Papinianus' career, see CIL 6.228 = ILS 2187 (Roma); HA, Vita Carac. 8; Vita Sev. Alex. 25, 6; Digesta 20, 5, 12; 22, 1, 3, 3. According to Peachin (1992), Papinianus may have been a member of the consilium of praetorian prefect Veturius Macrinus. 
with the style of the subscriptiones written between 205 and $209 .{ }^{66}$ In 222. Ulpianus was praefectus annonae and under Severus Alexander he was praefectus praetorio for a brief period, as will be discussed below in section $3.3 .{ }^{67}$ Strangely, no actual post of Iulius Paulus is reliably attested. He seems to have been a member of Papinianus' council and he may have been an a cognitionibus. It is unclear whether he was formally called a consiliarius, nor is there any confirmation of the Historia Augusta's statement that he became praetorian prefect under Severus Alexander. Yet a series of passages from his writings composed during the reigns of the Severi refer to discussions within the imperial consilium in which he took part. ${ }^{68}$

Other examples of high-ranking jurists include Modestinus and Rufinus. Honoré suggests that a man named Herennius Modestinus may have been a libellis in 223, but his solely stylistic arguments remain disputable. ${ }^{69}$ He was a iuris peritus, a learned jurist, apppointed to teach the son of the emperor Maximinus Thrax, according to the Historia Augusta. Modestinus was a pupil of Ulpianus and he ultimately reached the position of praefectus vigilum. That Modestinus was at least a renowned lawyer in the reign of Gordianus III emerges from a passage in the Codex Iustinianus to be dated in $\mathrm{AD} 239$, in which the emperor reminds a petitioner that Modestinus, 'a jurisconsult of no insignificant auctoritas' had already sent him a ruling on the same matter. ${ }^{70}$ Modestinus disappears from the sources about $241 .^{71}$

${ }^{66}$ On Ulpianus' early career, see Digesta 4, 2, 9, 3; HA, Vita Pesc. Nig. 7, 4; Vita Sev. Alex. 26, 5-6. Cf. Eutropius, Breviarium, 8, 23; Festus, Breviarium, 22. His career is discussed by Honoré (2002), 1-36.

${ }^{67}$ On Ulpianus as praefectus annonae and praetorian prefect, see Cod. Iust. 8, 37, 4; 4, 65, 4; HA, Vita Sev. Alex. 68, 1. According to HA, Vita Elag. 16, 4, Ulpianus was dismissed by Elagabalus, but it is unclear which position he held at that time and whether this statement is true. Aurelius Victor, Liber de Caesaribus 24, 6, seems to be mistaken when he reports that Elagabalus made Ulpianus praetorian prefect.

68 Paulus as a member of Papinianus' council see Digesta 12, 1, 40; for discussions on the imperial consilium in which Paulus took part see Digesta 4, 4, 38; 14, 5, 8; 32, 27, 1; 36, 1, 76, 1; on Paulus as praetorian prefect, see HA, Vita Pesc. Niger 7, 4; Vita Sev. Alex. 26, 5; Syme (1991), 216, argues that Paulus probably never was a praetorian prefect.

${ }^{69}$ On the suggestion that Modestinus was a libellis see Honoré (1994), 104-107; cf. Honoré (2002), 33. Millar (1999) accepts Honorés hypothesis.

70 Cod. Iust. 3, 42, 5: 'a non contemnendae auctoritatis iuris consulto', cf. Millar (1999), 102.

${ }^{71}$ On Modestinus, see PIR ${ }^{2} \mathrm{H} 112$ and M 655; Modestinus as praefectus vigilum: CIL 6.266 (Roma); tutor of Maximinus Iunior: HA, Vita Max. 27, 5; he may have been procurator in Dalmatia and was Ulpianus' pupil (Digesta 47, 2, 52, 20); Cf. Kunkel (1967), 259-261, no. 72 . 
The career of a man named Gnaius Licinius Rufinus has been reconstructed from a number of Greek inscriptions. This Rufinus, who apparently was Paulus' student, started his career under Septimius Severus and seems to have been consiliarius Augusti, ab epistulis Graecis, and $a$ studiis (an official connected with the emperor's judicial activity) respectively. Thereafter, he may have been a rationibus and a libellis, perhaps as Modestinus' predecessor or successor, after which he seems to have been accepted into the senate. He was praetor, governor of Noricum and finally gained consular rank by holding a suffect consulate or adlectio inter consulares. It has been suggested that Licinius Rufinus was one of the vigintiviri in $238 .{ }^{72}$ While others seem to have been a libellis under the Severi and entered the senate in an advanced stage of their career, which indicates that the Severan emperors were inclined to promote such intellectuals to senatorial rank, Rufinus is noteworthy in that an inscription set up in Thyatira explicitly mentions his equestrian rank (iллıxóv,

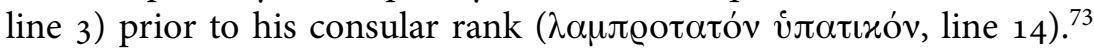
Modestinus and Rufinus may have been the last great jurists who exercised particular influence in the emperors' entourage. After that date, probably even from 230 onward, the role of identifiable legal writers at the emperor's side ceased and learned jurists seemed to have disappeared from the center of power. If Rufinus had indeed been one of the vigintiviri, his involvement in 238 may have hastened jurists' ensuing obscurity in imperial entourages after the 230 s. $^{74}$

According to De Blois, jurists continued to secure appointments $a$ libellis after about 240 and maintained high a quality of work there, but the style of rescripts changed and they seem no longer to have written scholarly works like those of Ulpianus. Jurists no longer reached the highest equestrian posts. De Blois posits that the learned jurists entered the consilia of the iudices vice Caesaris, the deputies of the emperor who took over judicial functions of the Augusti from the reign of Septimius

72 On Rufinus, see TAM V.2, no. 984-988 = IGRR IV, no. 1215-1218, and an inscription published by Hermann (1997), 111. Rufinus' career is reevaluated in Millar (1999). Rufinus as Paulus' pupil, see Digesta 40, 13, 4. On Rufinus as vigintivir in 238, see Herrmann (1997), 121, and Millar (1999), 96.

${ }^{73}$ Other examples of $a$ libellis who entered the senate under the Severi were P. Aelius Coeranus (Dio 77, 5, 3-5; PIR ${ }^{2}$ A 161), an eques who became consul suffectus circa 212 (cf. Leunissen (1989), 173), and M. Ulpius Ofellius Theodorus (PIR V 560; RE Suppl. 14, 942, s.v. Ulpius 44), a libellis under Caracalla (SEG 37, 1186, line 11) and consular governor of Cappadocia under Elagabalus. Cf. Millar (1999), 95; 97.

${ }^{74}$ Millar (1992), 97, identifies Aurelius Arcadius Charisius, magister libellorum at about $\mathrm{AD} 300$, as the next identifiable legal writer at court. 
Severus, as discussed in Chapter 1. He argues that the rise of those deputies may have contributed to the relative lowering of the learned jurists' status. Furthermore, he claims that patronage and recommendation structures no longer worked in favor of the, mainly Rome-based, learned jurists. ${ }^{75}$

It is not until Traianus or Hadrianus that we find examples of Millar's second category: men who were promoted from an equestrian career to become imperial secretaries. Obviously, such men were property-owners of some standing, who may be presumed to have had the usual GraecoRoman upper class literary education, but who were not promoted into the imperial entourage on the basis of their cultural and scholarly background, as the intellectuals did. ${ }^{76} \mathrm{~A}$ man who went through the full range of military and civilian posts before becoming ab epistulis under Marcus Aurelius and Lucius Verus, was Varius Clemens from Noricum. After a long succession of military posts, he held a series of provincial procuratorships, culminating in the procuratorship of Belgica and the two Germaniae, before he was finally appointed ab epistulis. ${ }^{77}$ Millar compares Clemens' background with that of other $a b$ epistulis to striking results. Since the concerns of most secretarial posts was essentially verbal, literary men dominated these positions. ${ }^{78}$ In Clemens' days, the careers of the military upstarts Pertinax and Valerius Maximianus seem to have been furthered, but so were those of three former senatorial legati legionis: Claudius Fronto, Martius Verus and Avidius Cassius, who were rapidly promoted to militarily important governorships of consular provinces. ${ }^{79}$ The flourishing careers of these five men confirms Birley's hypothesis that the ab epistulis was in a position to recommend men to the emperor and that the appointment of Clemens as ab epistulis was thus vitally important to them. ${ }^{80}$

Unfortunately, the evidence on the careers of those who served as imperial secretaries is very slight and becomes ever more scattered from the late second century onwards. Noteworthy is the career of Marcius

75 De Blois (2001), 147-149.

76 On this group, see Millar (1992), 101-110.

77 Pflaum (1960-1961), vol. 1, 368-373, no. 156.

78 Millar (1992), 105-106.

79 On Claudius Fronto, see PIR ${ }^{2}$ C 874; on Martius Verus, see PIR ${ }^{2}$ M 348; on Avidius Cassius, see $P I R^{2} A$ 1402. See also Alföldy (1977), passim, on them.

80 Birley (1992), 23; 27; 48 no. 8, in which Birley argues that the office of ab epistulis was an important center of information on possible candidates for all kind of posts, the most important broker at court; cf. De Blois (2001), 149. 
Claudius Agrippa. According to Dio's account, he was born a slave and became advcocatus fisci under Septimius Severus. He was exiled by this emperor and later recalled by Caracalla, who made him a cognitionibus and ab epistulis circa 215. Agrippa was then enrolled in the ordo senatorius (adlectio inter praetorios). Under Macrinus, Agrippa allegedly became governor of Pannonia Inferior and later of Dacia and Moesia Inferior. ${ }^{81}$ Agrippa's career is a fine example of the potential advantages of being close to the emperor as his secretary. Why a man who was exiled by Severus was taken back in service by Caracalla and appointed at posts which involved presence in the emperor's entourage is of course an interesting, though inexplicable, question.

After circa 240, information on imperial secretaries becomes scarce, if there is any information at all. That the imperial secretaries seem to have vanished from the earth is an inexplicable phenomenon. A passage from Philostratus demonstrates that under Marcus Aurelius the ab epistulis accompanied the emperor when he resided in Sirmium between military campaigns in Pannonia in the 170 os $^{82}$ Changing priorities, as discussed in Chapter 1, may have caused the emperors after 240 to spend less time on non-military matters and certainly affected that the emperors encountered more military specialists than sophists and lawyers. The fact that even Marcus Aurelius rejected one case due to his military activity may further imply that handling legal matters was eventually no longer selfevident for emperors on campaign. ${ }^{83}$ Whether imperial secretaries were eventually no longer taken along on imperial journeys and expeditions, or became invisible within a more bureaucratic administrative system in the second half of the third century, is a problem which cannot be solved for lack of evidence.

In conclusion we can say that some of the high equestrians indeed played an ever increasing role in third-century imperial administration in various spheres of power. This trend opened up opportunities for those

${ }^{81}$ Dio 79, 13, 2-4. Whether he was identical with the Marcius Agrippa mentioned in HA, Vita Car. 6, 7 as commander of the fleet and one of the accomplices in the murder of Caracalla is unclear. Cf. Jones (1942), who thinks Agrippa had no naval career. On Marcius Agrippa, see $P I R^{2} \mathrm{M} 224$.

82 Philostratus, Vitae Sophistarum, 2, 5. On this matter, see also Millar (1992), 5-6.

${ }^{83}$ Millar (1992), 6, citing an Athenian inscription on which Marcus rejects a case, stating: 'in order that after so long he shall not have to wait for the opportune moments in which it will be possible for me to judge the cases which need a decision precisely at the time of our military activity.' 
equites involved, which no members of the ordo had experienced in previous centuries, and this clearly affected their level of power positively.

Sophists and jurists were the first who saw their opportunities at court increase. Their rise started under Marcus Aurelius and lasted until circa 230, perhaps somewhat longer-until 240-in the case of the jurists. Yet after the age of the Severi, the dominant role of these intellectuals within the imperial council seems to have been assumed by other people at court: specialists in military tactics and logistics, in fiscal administration, taxation and requisition. As emperors visited Rome less frequently, military men and administrators who were present in the emperor's entourage or met him and his leading advisers in the field gained more influence. Such men could then promoted careers of people who helped them in their work, i.e. military cadre personnel. The military cadres consisting of centurions, primipili, tribuni, and praefecti, who were in a position to influence the soldiers and whose role in the fiscal and provincial administration became ever more important, could no longer go ignored in imperial appointment policies. The situation of crisis, in which Varius Clemens had been able to further the careers of military experienced men like Pertinax and Maximianus during Marcus Aurelius' wars in the Danube regions, became a permanent state of affairs from 230 onward. From those days, the power of militarily-skilled men seems to have gradually improved at the expense of non-military intellectuals and elite, both equestrians and senators. The equestrians, however, did not appropriate senators' roles in the central administration of the Empire either suddenly or completely. The process lasted several decades, at the end of which senators were still not ousted everywhere.

\subsection{The Status of High-ranking Equestrians in the Third Century}

These changes in power must have affected the status of at least those high-ranking equestrians who personally increased their power, and may even have elevated the status of the ordo as a whole. Again, however, for modern scholars it is much more complex to detect these consequences for their status than to perceive expansions in the spheres of their power. Still, some observations can be made on the matter.

First of all, intellectuals. The sophists and jurists increased their power as a result of their high status. Almost all these men originated from 
the highest circles at urban and provincial levels, and their education and scholarly reputation drew them into the emperor's entourage. Their verbal and intellectual abilities qualified them exceptionally well to perform secretarial duties in the emperor's service, as long as the emperors stayed based in Rome and spent most of their time carrying out non-military duties. ${ }^{84}$ Consequently, it is no surprise that from the 230 , when the emperors were obliged to focus their attention ever more on military crises, the role of the intellectuals in imperial administration changed. Intellectuals did not immediately and entirely disappear from the emperor's entourage, as for instance the role of Plotinus and his circle during the reign of Gallienus demonstrates, but their active involvement in the central administration of the Empire was drastically reduced ${ }^{85}$ These intellectuals thus represented a category within the equester ordo of notables who were defined by their (landed) property and who reached their high positions within the emperor's service through education (paideia) and status at the local level. ${ }^{86}$ Such intellectuals could reach the highest-ranking equestrian prefectures, which involved a high level of status, or they could even be elevated to senatorial rank.

Alongside these eminent equites another group arose that became increasingly important within the ordo in the third century, namely military professionals who had risen from soldier ranks to equestrian rank. ${ }^{87}$ They owed their high status in the emperor's service to experience and participation in imperial power. The equestrian census which had hindered entry into the equestrian order for such men in the first and second centuries was apparently no longer an obstacle. ${ }^{88}$ What began in the early third century as a minority eventually became the dominant power circle among the equestrians, a development which is most clearly noticeable if we consider the sort of men who reached the imperial throne between AD 268 and 284. High military commands and a growing number of provincial governorships were gradually conferred upon

${ }^{84}$ Cf. Millar (1992), 97, who argues that the role which these intellectuals, orators and jurists 'played at the emperor's side was an important aspect of the capture of the emperor by the ruling circles of the provincial cities.'

${ }^{85}$ On Gallienus and the circle of Plotinus, see for instance Porphyrius, Vita Plotini 12; cf. De Blois, (1976), 145-147, and 185-193; on Plotinus and his sympathizers turning their backs on practical politics, see De Blois (1989); De Blois (1994), 172-174.

${ }^{86}$ On the role of intellectuals at the local level, see also Slootjes (2009).

${ }^{87}$ Cf. Christol (1999).

${ }^{88}$ Cf. Heil (2008b), 749. 
high equestrian men instead of senators. Yet until the 260 s these transformations were presented as temporary solutions, for equestrians were appointed as agentes vice. The increased power of these equites was not formalized and thus not officially acknowledged. This may have obscured the growth of such equites' power for other groups involved in imperial administration, both at the central and the local level-and possibly even to these equites themselves - and it may have impeded, or at least delayed, an increase of these equites' status.

Another factor may have distorted on the perception of changes in the ordo's relative status: in the course of the third century, especially from the 250 onward, high-ranking equites were promoted to senatorial rank less often. The limited number of homines novi detectable in the second half of the third century may indicate that senatorial status had become less attractive to men in such high equestrian posts, or that emperors no longer saw any need to elevate them to senatorial rank. One could also argue that emperors did not consider these military men appropriate candidates to enter the senate. Yet second-century examples of men with a similar military background and career who were accepted into the senate seem to refute this argument.

Eventually, however, increasing status followed increased power for these equestrians involved in military matters and provincial government. This process started low-profile with the extension of the perfectissimate in gradual stages. As Pflaum has demonstrated, a growing number of equestrian officers were awarded with the title vir perfectissimus instead of vir egregius. ${ }^{89}$ Under the Severi, the title was reserved for the high equestrian prefects (the praefecti annonae, vigilum, and Aegypti) and imperial secretaries. In the reign of Gordianus III, the title was also bestowed upon a praefectus classis and a procurator of Mauretania Caesariensis. From the 26os, the title perfectissimus also went to equestrian provincial praesides and even to a $d u x .^{90}$ That from the late 260 on onward the emperors themselves were mostly equestrians was probably a result from the rise in status of such military equestrian upstarts. Only under

${ }^{89}$ Pflaum (1970). Just as senators adopted the epithet clarissimus to express their rank, equestrian official developed a hierarchy of epithets: egregius, perfectissimus, eminentissimus. Vir eminentissimus was the normal and exclusive title of the praetorian prefect until the reign of Septimius Severus. Cf. Salway (2006), 119. On the inflation in titles and the extension of the eminentissimate to prefects of the second rank under Severus and Caracalla, see Salway (2006), 123-124.

90 See Pflaum (1960-1961), vol. 2, 624, note 10, for a list of perfectissimi viri in the third century. Cf. Pflaum (1970), 177-178. 
the emperor Constantine, this process of elevation of status for high equestrians came to an end, as he granted all high equestrians senatorial status. ${ }^{91}$

\subsection{The praefecti praetorio: A Case Study}

A case study on the power and status of the praetorian prefects may yield additional or more specific insights about the developing position of those members of the ordo equester whom third-century changes affected. Admittedly, the case of the praefectus praetorio is in a certain way unrepresentative of all high-ranking equestrians, as it does not illustrate a shift from senatorial to equestrian power: from the establishment of the position in $2 \mathrm{BC}$ the post of commander of the cohortes praetorianae, whose basic function it was to guard the emperor's life, had been assigned to men of equestrian rank. Yet, as it is the only equestrian position on which we have evidence of its holders' identities and authorities on a more or less continuous basis, this case study can display the process of the increasing power and status in more detail. Furthermore, the case of the praetorian prefect can demonstrate how the changing position of the equestrian officer affected his relation with the senatorial elite and the emperors, the other main power groups within the administration of the Empire.

The uniqueness of the praetorian prefecture, combined with the fact that we are relatively well informed on the prefects' identities has inspired many scholars to examine both the officeholders and the office in itself during the Principate. ${ }^{92}$ Their works have been invaluable for the examination on the position of the praetorian prefects in the period AD 193 to 284 which follows.

${ }^{91}$ Salway (2006), 132-135.

92 Mommsen (1899), 267-269, and Stein (1963), passim, discussed certain aspects of the prefecture in their studies of Roman law and the equestrian order respectively, whereas Durry (1938, second edition 1968) and Passerini (1939) dealt with the praetorian prefecture and its holders incidentally in their studies of the praetorian cohorts in the 1930s. Howe (1942) was the first to devote a monograph to the history and development of the pre-Constantinian prefecture. He was mainly concerned with how the office, in origin purely military, became a purely civil one under Constantine. While Howe's extensive prosopography of officeholders and his other appendices, with which he amplified and refined our knowledge on the third-century prefecture, won high praise, his interpretation of the constitutional position of the prefect of the praetorian guard was not that well received. Cf. Giles (1943); Reinhold (1943); Reinmuth (1944); Last (1944); Lewis (1945). On the praetorian prefecture during the Principate, see also RE 22 (1954), s.v. Praefectus 


\section{The Power of the Praetorian Prefects: Military Authority}

From the establishment of the office, the primary duty of the praetorian prefects was of course to protect the emperor and the imperial family. Some examples indicate that this still fell within their range of duties in the third century. For instance, Flavius Genialis, prefect under Didius Iulianus, was with the emperor until the end of his life..$^{93}$ Genialis' final fate is not recorded, but it is not unlikely that he died while attempting to guard the emperor. Antiochianus and an unnamed colleague, praetorian prefects under Elagabalus, allegedly pacified the praetorians when they rioted, fearing that the emperor would harm Caesar Severus Alexander. Antiochianus persuaded a small number of praetorians who had come to the palace not to kill the emperor, while the other prefect was sent to the praetorians' camp and convinced them to spare Elagabalus. Antiochianus and his colleague may also have been the anonymous prefects who perished with Elagabalus in 222. ${ }^{94}$ If we may believe Zosimus, Severus Alexander's prefects found themselves in the presence of his mother Iulia Mamaea in the palace after the emperor had died; they were killed along with the empress. ${ }^{95}$ In their capacity as bodyguards, praetorian prefects regularly accompanied emperors on their journeys. Third-century praetorian prefects are attested regularly as imperial comites, joining emperors on military expeditions. An inscription from Rome demonstrates that Plautianus was comes of Septimius Severus and Caracalla on all their expeditions until his downfall in 205, and Dio suggests that Papinianus was in Britannia with Severus and his sons. ${ }^{96}$ Both Macrinus and Oclatinius Adventus seem to have been present as prefects in Mesopotamia when Caracalla was killed, joining him on his Parthian expedition. A

praetorio, 2391-2426 (in 2426-2502, Enßlin deals with the prefecture in Late Antiquity); Chastagnol (1970) with a list of prefects between AD 202 and 326; Millar (1992), 122-131; Absil (1997/ 1998), dealing with the prefects from Augustus to Commodus; De Blois (2001), focusing on the role of jurists as prefects; Eich (2005), 211-257. Chastagnol (1968) and Barnes (1992) specifically deal with the prefecture after AD 284. A list of known praefecti praetorio between AD 193 and 284 can be found in Appendix 3.

${ }_{93}$ HA, Vita Did. Iul. 3, 1; 8, 6-8.

${ }^{94}$ HA, Vita Elag. 14-15; cf. Dio 79, 21, 1. On Antiochianus, see also $P I R^{2}$ A 738. If Antiochianus was indeed one of the prefects who died along with Elagabalus, he cannot have been identical with the Antiochianus to whom Severus Alexander addressed Cod. Iust. 6, 35, 3 in $\mathrm{AD} 222$.

95 Zosimus 1, 13, 2.

${ }^{96}$ Plautianus: CIL 6.1074 $=I L S 456=A E$ 1954, 245 (Roma): '[ . . ] comitis per omnes expeditiones eorum'. Papinianus: Dio 77, 14, 5-6. 
prefect of the guard, possibly Macrinus or Adventus, also accompanied Caracalla on his journey through Thracia in $214 .{ }^{97}$ Elagabalus' prefect, ... atus, whose full name is unknown, is attested as comes et amicus fidissimus of the emperor, although it cannot be determined whether he was comes during his prefecture or prior to it. ${ }^{98}$

Some references indicate that even when, after the Severan era, praetorian prefects were increasingly sent on assignment detached from the emperors, as will be discussed below, prefects occasionally still found themselves in the imperial entourage. Successianus, praetorian prefect of Valerianus according to Zosimus, is said to have helped the ruler in the restoration of Antiocheia, which was ruined either by an earthquake or during a Persian attack. He probably was the हैं $\alpha \varrho \chi 0 \varsigma$ who was captured by the Persians along with the emperor. ${ }^{99}$ Not long after Valerianus had been captured, Gallienus promoted his praefectus vigilum Volusianus to the rank of praefectus praetorio. Both the emperor and Volusianus were in Rome when they were colleagues as consules ordinarii in 261, and it is likely that Volusianus regularly was a member of the imperial entourage during the next few years, when Gallienus spent most of his time in Italy. ${ }^{100}$ When the emperor left the capital to fight the Goths and Heruli at the end of 266, he left Rome in the hands of Volusianus, who then became praefectus urbi. Heraclianus, who succeeded Volusianus as praetorian prefect, was present in Gallienus' entourage when the emperor returned to Italy to put down the revolt of Aureolus. Yet he became an example of a disloyal prefect, as several sources attest that he was the one who instigated the murder of Gallienus. ${ }^{101}$

The bond between an emperor and his praetorian prefect was based on loyalty. On occasion, an emperor retained in office a prefect who was installed by his predecessor, as Septimius Severus allegedly did with

97 Macrinus and Adventus in Mesopotamia: Dio 79, 3-5; 79, 14; Herodianus 4, 12-14. Thracia: Dio 78, 16, 7; Herodianus 4, 8, 1; HA, Vita Carac. 5, 8. See also Halfmann (1986), 224 .

${ }_{98}$ CIL $6.41190=6.3839 \mathrm{a}=6.31776 \mathrm{a}=I L S_{1329}=A E 2003,182$ (Roma). It has been suggested that this prefect $\ldots$ atus was identical with T. Messius Extricatus, but this conjecture has been rejected by Salway (1997).

${ }_{99}$ Res Gestae Divi Saporis 11, translation Frye (1984), 372.

100 Halfmann (1986), 237-238, on Gallienus' presence in Italy. The main part of Volusianus' career can be deduced from CIL 10.1706 (Arretium, Italy), probably erected circa 261. Cf. HA, Vita Gall. 1, 2. On Volusianus' career, see also section 4.2.

${ }^{101}$ HA, Gall. 13-14; Zosimus 1, 40, 2-3; Zonaras 12, 25. See also Goltz-Hartmann (2008), 289-292. 
Flavius Iuvenalis and Diocletian with Aristobulus, but usually an emperor personally selected his praetorian prefect(s). ${ }^{102}$ Trust seems to have been of overriding importance in the emperor's selection process, and even appears to have overruled a candidate's experience and background. As the only man who was allowed to be armed in the emperor's presence, a prefect could easily become involved in political intrigues. A crisis of loyalty between the emperor and his praetorian prefect meant the end of one of them. Aemilius Laetus, for example, engineered the death of Commodus and the election of Pertinax in 193. He overplayed his hand by betraying Pertinax as well: Pertinax' successor Didius Iulianus replaced him and put him to death soon afterward. ${ }^{103}$ Literary sources mention a split between Septimius Severus and Plautianus, caused by an incident in 203. According to Dio, Severus was displeased at the large number of statues of Plautianus, and ordered that some of them were to be melted down, which caused the rumor that the prefect had been overthrown. The Historia Augusta reports that Severus declared Plautianus a public enemy and that he destroyed Plautianus' statues after the prefect had set up his own statue among the statues of Severus' kinsmen. Although the two were reconciled by the time Severus returned to Rome in 204, the damage could not be repaired completely and a final split between the emperor and his prefect produced Plautianus' death in January 205. ${ }^{104}$ About a decade later, Macrinus' betrayed and murdered Caracalla, thus becoming the first praetorian prefect who was acclaimed emperor. Most sources state that the emperor Philippus Arabs, praetorian prefect under Gordianus III, was also involved in the latter's death. ${ }^{105}$ Heraclianus' disloyalty toward Gallienus mentioned above, was punished mercilessly by Claudius Gothicus, who discarded him, after which Heraclianus committed suicide. ${ }^{106}$ In 284, Flavius Aper, prefect

102 Flavius Iuvenalis: HA, Vita Sev. 6, 5. Aristobulus: Aurelius Victor, Liber de Caesaribus 39, 14; cf. Ammianus Marcellinus 23, 1, 1. Perhaps this was also the case with Veturius Macrinus, who was appointed praetorian prefect by Didius Iulianus as a peace gesture to Severus, according to HA, Vita Did. Iul. 7, 4. However, it is unclear whether this appointment was confirmed by Severus. See Howe (1942), 68-69.

103 Dio 73, 22; 74, 1; 74, 6-9; 74, 16; Herodianus 1, 17; 2, 1-3; HA, Vita Comm. 17, 1; Vita Pert. 4-5; 10, 9; Vita Did. Iul. 6, 2.

${ }_{104}$ Dio 76, 16, 2; HA, Vita Sev. 14, 5-6.

${ }^{105}$ HA, Vita Gord. 29-30; Zosimus 1, 18; Zonaras 12, 18. See Potter (1990), 204-212, on the confused tradition.

106 Zonaras 12, 25. Potter (2004), 264-267, suggests that Heraclianus was sent on expedition in the East by Claudius in 270 and committed suicide after failing to restore Roman authority there. 
under Carus and later under Numerianus, was accused of the latter's death and killed by Numerianus' imperial successor Diocletian. ${ }^{107}$

Because loyalty to and mutual trust with the emperor were essential to the prefectship, it is no surprise that emperors regularly chose friends or relatives as their praetorian prefects. Third-century examples include Priscus and Florianus, and perhaps Plautianus and Papinianus. According to the Historia Augusta, Pupienus chose an uncle (patruus), Pinarius Valens, as his prefect. The same source states that Gordianus III sought to replace Philippus as prefect with his relative Maecius Gordianus at the end of his reign. The inclusion of these examples, even if they are not all historically correct, shows that for both the author and his audience the appointment of relatives was plausible. The reason for this practice was evident: a relative had a natural bond with the emperor and could thus be assumed a loyal ally. Occasionally, however, it happened the other way around: a prefect could be included in the imperial family. Septimius Severus included Plautianus in the domus divina by making him Caracalla's father-in-law. Timesitheus became the emperor Gordianus III's own father-in-law, as did Flavius Aper, prefect under Numerianus. ${ }^{108}$

To further reduce the chance of abuse of power, emperors generally appointed two praetorian prefects to perform the prefecture simultaneously. At the beginning of the third century, this certainly still was common practice: Flavius Genialis and Tullius Crispinus were colleagues under Didius Iulianus, and Plautianus had Aemilius Saturninus as his colleague during Septimius Severus' reign. It is generally assumed that Plautianus was sole prefect from the day Saturninus died very soon after his appointment. ${ }^{109}$ Papinianus seems to have had Maecius Laetus

107 HA, Vita Car. 12-13; 15, 4; Aurelius Victor, Liber de Caesaribus, 38, 4-6; 39, 14; Eutropius, Breviarium, 9, 18-20; Zonaras 12, 30-31.

108 On Priscus, brother of Philippus Arabs, see Zosimus 1, 19, 2; on Plautianus as kinsman of Septimius Severus, see Herodianus 3, 10, 6; on Plautianus as Caracalla's fatherin-law, see Dio 77, 1, 2; Herodianus 3, 10, 7; on Papinianus as relative of Iulia Domna, see HA, Vita Carac. 8, 2; on Florianus, brother of Tacitus, see HA, Vita Tac. 14, 1; 17, 4: Aurelius Victor, Liber de Caesaribus 36, 2; on Pinarius Valens, kinsman of Pupienus, see HA, Vita Max.-Balb. 4, 4; 5, 5; on Maecius Gordianus, relative of Gordianus, see HA, Vita Gord. 30, 1; on Timesitheus, father-in-law of Gordianus, see HA, Gord. 23, 6; Zosimus 1, 17, 2; on Flavius Aper as father-in-law of Numerianus, see HA, Vita Car. 12, 1. In some cases, prefects acted as tutors of young Caesares or Augusti: Papinianus is attested as Geta's and Caracalla's tutor (HA, Vita Car. 8, 3) and Silvanus, if he was indeed praetorian prefect, was entrusted with the care of Gallienus' son Saloninus in Cologne. See Bleckmann (1992), 245, with further references. On Silvanus as praetorian prefect, see Howe (1942), 81, no. 50; König (1981), 47; Johne-Hartmann-Gerhardt (2008), 1075.

109 Dio 76, 14, 2, accuses Plautianus of Saturninus' death. 
and then Valerius Patruinus as colleagues. ${ }^{110}$ Under Caracalla, Oclatinius Adventus and Macrinus may have divided the military and non-military tasks of the prefecture, as the former was a vir militaris and the latter a juridically skilled bureaucrat. ${ }^{111}$ Macrinus as emperor chose two militarily experienced prefects, Iulianus and Nestor. As has been noted above, the literary evidence attests that under Elagabalus there were two simultaneously operating prefects, Antiochianus and his anonymous colleague. Severus Alexander allegedly appointed Ulpianus as a third prefect over Flavianus and Chrestus in a supervisory role. Later, Ulpianus had them put to death and became sole prefect. ${ }^{112}$ The last pairs of prefects can be found in the early 240 os under Gordianus III: Timesitheus and Priscus, and finally Priscus and Philippus. ${ }^{113}$ From the reign of Philippus Arabs onward, there is very little evidence pointing to pairs of prefects. Valerianus and Gallienus may each have had their own prefect or perhaps even prefects, but unfortunately the evidence does not yield definite conclusions.

Along with their primary task of guarding the emperor and commanding the praetorian cohorts, both in times of peace and mobilized in battles, the praetorian prefects occasionally commanded additional troops. This practice started as early as the end of the first century AD. ${ }^{114}$ When an emperor did not want to leave a crucial military expedition to a provincial governor, and he could not lead the troops in person, it frequently was the praetorian prefect who appeared as commander-in-chief of a field army and who held the title of supreme commander vice principis. In the third century, there are plenty of cases in which a praefectus praetorio acted as commander of large military units, even (detachments of) legions. In 218, for example, Macrinus' praetorian prefect Ulpius Iulianus was apparently commanding troops in Syria when Elagabalus attempted to seize imperial power. The sources disagree on whether Iulianus acted on his own initiative or by orders of Macrinus. Iulianus' soldiers deserted to Elagabalus, cut off their commander's head and sent it back to Macri-

\footnotetext{
110 Howe (1942), 72-72.

111 On Oclatinius Adventus' career, see also section 4.1; on Macrinus' career, see later in this section.

112 Dio 8o, 2, 2, pp. 480-481; Zosimus 1, 11, 2-3; Zonaras 12, 15. See Honoré (2002), $30-32 ; 35-36$, with further references.

${ }^{113}$ Howe (1942), 78-80, supplying further references. Cf. Körner (2002), 55-57; 72-74.

114 Cornelius Fuscus, prefect under Domitianus, commanded an army on the Dacian front: Suetonius, Domit. 6, 1; Dio 67, 6, 5-6; Eutropius, Breviarium, 7, 23; Orosius 7, 10, 4. Marcius Turbo as supreme commander in Pannonia and Dacia under Hadrianus (circa AD 119): Dio 69, 18; HA, Vita Hadr. 6, 7; 7, 3.
} 
nus. ${ }^{115}$ In the 240s, when the Sassanids invaded Mesopotamia under Shapur I, a huge army marched to the East under Timesitheus, guard prefect of Gordianus III. ${ }^{116}$ As discussed in section 3.1, Timesitheus had gained experience as military chief under Severus Alexander, when he acted as deputy governor of Germania Inferior and commanded the legions $X X X$ Ulpia Victrix and I Minervia. ${ }^{117}$ If we may believe the Historia Augusta, Timesitheus was rather good in communicating with military men and a very capable army commander, and so was de facto even more powerful than his son-in-law Gordianus III. ${ }^{118}$ After Timesitheus died, his successors Priscus and Philippus became Gordianus' greatest deputies during the disastrous campaign against the Persians in the winter of $243 / 244{ }^{119}$ Valerianus' prefect Successianus thus fought the Persians in the presence of the emperor, as they were captured together in 260. Yet Ballista, who may have been his colleague, is said to have campaigned successfully against the Persians as well. He clearly operated elsewhere, was not caught and defeated the enemy soon after. ${ }^{120}$ Ten years later, praefectus vigilum Placidianus, who was commanding an army detachment in Gallia that had been sent against the Goths or the Gallic empire or against both by Claudius, was promoted to the position of praetorian prefect by Aurelianus. Considering the fact that the inscription mentioning Placidianus as prefect was found in Gallia, he obviously did not resign his command immediately. ${ }^{121}$ In 282, Probus' prefect Carus was commanding

115 Dio 79, 31; Herodianus 5, 4; HA, Vita Macr. 10, 1-3; Howe (1942), 26. Ulpius Iulianus probably commanded (troops from) legio II Parthica, Rome's strategic reserve which was usually stationed in Castra Albana in Italy. Iulianus' colleague Nestor apparently was in Syria at that time as well, as Dio $(80,3,4)$ reports that he was killed there by Elagabalus soon after Macrinus' death. It is not recorded, however, whether he acted as commander of troops as well.

${ }^{116}$ HA, Vita Gord. 26-27, 3 .

117 On this combined appointment, see Pflaum (1960-1961), vol. 2, no. 317, 815-816.

118 HA, Vita Gord. 28.

119 Zosimus 1, 18; Zonaras 12, 18; Körner (2002), 72-74, for further references. IGRR 3, 1033 (Palmyra, AD 242/ 243), most probably refers to Priscus and demonstrates that he already was praefectus praetorio under Gordianus. However, it cannot be determined whether he already held the position when Timesitheus was still alive or only after his death. Körner (55-56), suggests that Priscus was in Palmyra in those years to make preparations for Gordianus' expedition against the Persians. Cf. Howe (1942), 109.

120 Successianus: Zosimus 1, 32, 1-2; cf. Res Gestae Divi Saporis 11, translation Frye (1984), 372; Ballista: HA, Vita Val. 4, 4; Vita Trig. Tyr. 12, 1; 18; Zonaras 12, 23 (in which he is called Callistus). It is doubtful whether Ballista already was praetorian prefect under Valerianus, as he is only referred to as 'praefectus' in HA, Trig. Tyr. 12, 1; 18, 13. According to Desbordes-Ratti (2000), 94, he was not.

${ }^{121}$ According to CIL 12.2228 = ILS 569 (Gallia Narbonensis, AD 269), Placidianus was 
troops in Raetia when he was acclaimed emperor, while Probus was in Sirmium following a stay in Rome to celebrate a triumph after having subdued mutinies on the Rhine and in Britannia. ${ }^{122}$ According to the Historia Augusta, Carus was trained as a general $(d u x)$ by Probus himself. ${ }^{123}$

The legal basis for such military commands cannot be determined and it is not settled whether the praetorian prefects of the third century held a general command over the Roman army. ${ }^{124}$ Moreover, it is unclear whether Italic troops were under the praetorian prefect's command. Dio makes Maecenas so advise Augustus, but, as is well known, whether this reflected the historical reality of the early third century, or a suggestion for a reform by Dio, is unclear. ${ }^{125}$ From the reign of Septimius Severus the Italic troops included the Vigiles, the equites singulares, the troops in the Castra Peregrina, legio II Parthica, and the fleets which were based at Misenum and Ravenna. ${ }^{126}$ It is generally accepted that a praetorian prefect commanded the soldiers of the Castra Peregrina, but there is no evidence that the Vigiles and their commander, the praefectus vigilum, were subordinate to him. ${ }^{127}$ The fleets and legion II Parthica seem occasionally to have fought under the prefect's command. Didius Iulianus sent Crispinus to secure the fleet at Ravenna in 193, and Macrinus may have commanded the legio II Parthica during Caracalla's Parthian campaign in 216. By the time Caracalla was murdered, however, the command over II Parthica was no longer in Macrinus' hands, as Triccianus is reported as

in charge of vexillationes and equites as well as praepositi et ducenarii protectores. CIL 12.1551 (Gallia Narbonensis) mentions Placidianus as praefectus praetorio and is dated either 270 or 273 .

122 Triumph of Probus: HA, Vita Prob. 19; acclamation of Carus and death of Probus: HA, Vita Prob. 21; Zonaras 12, 29. See Kreucher (2003), 183, with further references.

${ }_{123}$ HA, Vita Prob. 22, 3.

124 Eich (2005), 214-215, points out that there is no evidence for a general command under the praetorian prefect. He argues that it is unlikely that it existed before the second half of the third century and that the information offered by sources for the second half of the period under discussion are too scanty to draw conclusions on this matter. Howe (1942), 25-26, asserts that such army commands originally were special delegations for particular campaigns. Cf. RE 22 (1954), s.v. praefectus praetorio, 2409 ff. Howe's detection of a tendency toward a more general delegation in the third century is controversial. See Eich (2005), 215, note 3 .

125 Dio 52, 24, 3.

126 The urban cohorts, which were originally placed under the command of the praefectus urbi, may have been passed into the control of the praetorian prefect in the second century. Yet, they seem to have been commanded by the city prefect during the reign of Caracalla, as the resistance of the urban cohorts to the praetorians sent to kill city prefect Fabius Cilo (Dio 78, 4, 2-5) demonstrates. Cf. Howe (1942), 22-23.

127 Eich (2005), 215-216, with further references. 
this legion's praefectus at that point. ${ }^{128}$ This indicates that the praetorian prefect had no permanent command over the legion. For now, it seems safe to argue that the praetorian prefect was the highest-ranking soldier in Italy in the third century, but that he was not necessarily the formal commander of all Italic troops. ${ }^{129}$ Eich argues that a formal subordination was unnecessary: in effect, the praetorian prefect was the obvious man to lead military operations in Italy if rapid intervention was desired. ${ }^{130} \mathrm{After}$ all, no other commander could undermine the prefect's position in Italy by virtue of prestige. The only imperial of higher rank was the city prefect, whose authority was limited to the city of Rome.

It is noteworthy that most examples of praetorian prefects acting as commander-in-chief of a field army date from the second half of the third century. By then, there were of course more active field armies, though we must keep in mind that the available evidence on this period, mainly non-contemporary historiographical sources, which are themselves frequently excerpts of other historical works, emphasize the military events of those decades, which may have distorted our perceptions. Yet, the number of prefects who were appointed before 240 with evident military experience is not high. Flavius Genialis, prefect of Didius Iulianus, had probably been tribunus of a (praetorian) cohort in 185 , but that is all we know of his career. ${ }^{131}$ Caracalla's prefect Oclatinius Adventus was obviously a vir militaris, whereas his colleague Macrinus allegedly endured regular mocking from Caracalla of his lack of military experience and bravery. ${ }^{132}$ As princeps of the Castra Peregrina Adventus commanded the frumentarii, who functioned as a sort of secret police in Rome. According to Dio, Ulpius Iulianus and Iulianus Nestor, Macrinus' prefects, had served as principes peregrinorum under Septimius Severus or Caracalla

${ }^{128}$ Crispinus securing the fleet: HA, Vita Did. Iul. 6, 3-4. Triccianus commanding II Parthica: Dio 79, 13, 4; HA, Vita Car. 6, 6. According to Eich (2005), 216, the reference to a soldier of II Parthica as strator of the praetorian prefect in CIL 6.3408 (Roma) is the only sign of permanent subordination of this legion to the prefect.

129 See also Nicols (1988), who argues that the praetorian prefects played an important role as patroni in Italy and were therefore mentioned among men of senatorial rank at the Album of Canusium.

130 Eich (2005), 216.

131 If he was indeed identical to the Genialis mentioned in CIL 6.214 (Roma), as Howe (1942), 68, no. 14, suggests. CIL 8.18065 = ILS 2452 = AE 1937, 157 (Numidia, AD 162), mentions a centurion of III Augusta who goes by the name Flavius Iuvenalis. He may have been identical with the prefect in 193 . The interval of time, however, leaves it more likely that the centurio was the prefect's homonymous father.

132 Herodianus 4, 12, 1; on Oclatinius Adventus, see Rankov (1987), 244-245; see also section 4.1. 
as well. Thus they had a similar military background. ${ }^{133}$ It is noteworthy that all three of them are recorded as accompanying their emperors on military expeditions and may have commanded field armies during these campaigns. Then there is Comazon, who started his career as a soldier in Thracia during the reign of Commodus and was commander of legio III Gallica in Syria in 218, before he became Elagabalus' praetorian prefect. ${ }^{134}$ Although very little is known of the career of almost half of the prefects appointed between 193 and 240, it may be concluded that military experience was no prerequisite: the appointments of jurists as praetorian prefects, which will be discussed in detail below, demonstrate that a career in the legal sphere could just as well lead to appointment as praetorian prefect in the Severan era. Moreover, as ever before, a considerable number of ex-prefects of Egypt were promoted to the rank of praetorian prefect, and in that way completed the equestrian cursus. ${ }^{135}$

However, a relatively large number of the praetorian prefects appointed after AD 240 had military experience. As noted, Timesitheus had gained it under Severus Alexander in his Persian expedition and in the Rhine area. Priscus' and Philippus' careers before the prefecture have not been recovered, but their role in Gordianus' Persian wars renders it unlikely that they never held military positions before the prefecture. Successianus chased away invading Scythians (i.e. Goths) as prefect of a Roman garrison before Valerianus called him to Syria and appointed him praetorian prefect. Gallienus' prefect Volusianus, one of the few prefects whose career is almost entirely known to us, was a true vir militaris. As has been mentioned above, Placidianus was commanding troops before he became praetorian prefect. According to the Historia Augusta, Carus' career included both civil and military offices. Zonaras calls him 'brave and skilled in war', and another passage of the Historia Augusta refers to him as one of the generals trained by Probus. Finally, Flavius Aper,

\footnotetext{
133 Dio 79, 15, 1.

134 Dio 80, 3, 5 .

135 (1) Veturius Macrinus, praefectus Aegypti 181-183, may have been identical to the praetorian prefect in 193-200; (2) Aemilius Saturninus was governor in Egypt in 197199 and praetorian prefect circa 200; (3) Maecius Laetus governed Egypt between 200 and 203 and was praetorian prefect between 205 and 211; (4) Iulius Basilianus is attested as praefectus Aegypti in 217-218, and subsequently became praetorian prefect in 218; (5) Geminius Chrestus was governor of Egypt in 219-220, and praetorian prefect in 222; (6) Domitius Honoratus was prefect of Egypt in 222, and praetorian prefect in 223; and (7) Aedinius Iulianus governed Egypt in 222-223, and became praefectus praetorio afterwards, probably circa 223. For more detailed information on these praefecti Aegypti and further references, see Jördens (2009), passim.
} 
appointed prefect by Carus in the 280s, may have been identical with the homonymous man who was praeses in Pannonia Inferior and perhaps also praepositus of two legionary detachments under Gallienus. ${ }^{136}$

In sum, third-century emperors deployed praetorian prefects more and more as troubleshooters, who headed military units and field armies while the emperors solved crises elsewhere. This the Severi did so occasionally, but such appointments became even more common from circa 240 onward. In times of need, the custom of the prefect accompanying the emperor on his journeys was apparently ignored. From Philippus' reign onward, another practice may have been altered: the available evidence indicates that emperors no longer (necessarily) appointed two simultaneously operating praetorian prefects. Of course, it must be taken into account that a lack of evidence may be rendering pairs of prefects untraceable. If true, however, this obviously raised the level of power which the single prefect could exercise: he now became the 'second man' in the Empire, without having to share this role. In addition, many praetorian prefects after the Severan era seem to have had a more concentrated military background. Logically, the increasing number of military crises, occurring simultaneously in various areas in the Empire, created a need for praetorian prefects who were capable of dealing with critical military situations by themselves. The military authority of the praetorian prefect thus seems to have increased, as he operated ever more independently over the course of the third century, especially in the second half. Whether this growing level of military power affected the non-military authority of the praetorian prefects will now be discussed.

\section{The Power of the Praetorian Prefects: Non-military Authority}

Beside military tasks, praetorian prefects had legal and civil-administrative duties. The prefects' jurisdiction had probably followed from their basic duty: as commanders of the imperial bodyguard, prefects had police powers in Rome. Accused men and prisoners were put under the prefect's control. Arrested men from the provinces, who were transported to

\footnotetext{
${ }^{136}$ For Timesitheus' career, see CIL $13.1807=$ ILS 1330 (Gallia Lugdunensis); Pflaum (1960-1961), vol. 2, no. 317, 815-816, and section 3.1. On Priscus and Philippus, see Körner (2002), 54-59, 72-74; 366-367. Based on Zosimus 1, 18, 3, De Blois (2001), 140-141, posits that Philippus was a specialist in military logistics. On Successianus, see Zosimus 1.32, 1-2. On Volusianus: CIL 10.1706 (Puteoli, Italy); PLRE I, s.v. Volusianus 6; cf. section 4.2; Placidianus: CIL 12.2228 (Gallia Narbonensis). On Carus, see HA, Vita Car. 5, 4; HA, Vita Prob. 22, 3; Zonaras 12, 30; On Aper, see: AE 1936, 53; 54 ; 57 (Pannonia Superior); CIL 3.15156 (Pannonia Inferior); PLRE I, s.v. Aper 2; cf. Aper 3.
} 
Rome, were handed over to him as well. In this capacity a prefect could also investigate cases of high treason. ${ }^{137}$ As a member of the emperor's council, moreover, the prefect both assisted in administering justice and in formulating imperial policy, praetorian prefects having participated in the imperial council from the first century onward. ${ }^{138}$ Whether the prefect's presence in the council was formalized at some point is disputed, but he seems to have participated on a regular basis ex officio.${ }^{139}$ Although little evidence explicitly mentions prefects in council meetings in the third century, it may be assumed that the prefects continued regularly to be present in the consilium, at least when they found themselves in the emperor's entourage. ${ }^{140}$ Little can be said about the specific role of the praetorian prefect within the imperial consilium, but because senators participated in it as well, Mommsen's suggestion that the praetorian prefect acted as vice-president, chairing meetings in the emperor's absence, seems unlikely. Senators would probably never have accepted the equestrian as president of the council, due to his lower social status. ${ }^{141}$

By the late second century AD, praetorian prefects exercised independent jurisdiction in Italy. Septimius Severus confirmed their jurisdiction in Italy beyond the hundredth milestone from Rome and made the prefect president over a separate court of law in the capital, in which the prefect exercised both an original and, more regularly, appellate jurisdiction. ${ }^{142}$ The praetorian prefect's autonomous jurisdiction may have represented an expansion of his regular participation in the consilium principis,

137 Cf. Plinius, Epistulae 10, 57; HA, Vita Sev. 4, 3; Cod. Iust. 4, 65, 4.

138 See Crook (1975) and Amarelli (1983) for detailed studies of the imperial council. Seianus participating in Tiberius' consilium: Suetonius, Tib. 55. For further references, see Eich (2005), 218, note 4. Contra Howe (1942), 32, who claims that the earliest reference to prefects as regular members of the consilium was from the time of Marcus Aurelius, based on HA, Vita Marc. 11, 10.

139 Cf. Eck (1998), 6.

140 See Howe (1942), 32-33; Eich (2005), 218-219, on this matter.

141 Mommsen (1887), vol. 2, 990; 1121. Contra Mommsen, see Durry (1968), 175; Passerini (1939), 261; Crook (1975), 98-99; Eich (2005), 218-219, note 1; cf. Howe (1942), 33, who argues that it is hard to see why the council would ever meet without the emperor, since its function was to advise him.

142 See CIL 9.2438 = AE 1983, 331 (Saepinum, Italy) for the prefect's jurisdiction in Italy under Marcus Aurelius. On the jurisdiction of the praefectus urbi within Rome, see Digesta 1, 12, 1, 4, although one should of course be aware that it is uncertain whether the situation described here applies to the Severan era, when Ulpianus wrote the text, to Iustinianus' reign, or both. On the praetorian prefect's jurisdiction in Italy, see Howe (1942), 34-35, and Eich (2005), 216, note 5, for further references. Howe (1942), 34, compares the praetorian prefect's jurisdiction for Italy to the judicial authority possessed by legati in the imperial provinces. 
but the emperors may also have delegated it to them. ${ }^{143}$ From the beginning of the third century onward, the prefect's decisions could theoretically no longer be challenged, as the prefect acted as the representative of the emperor (vice principis). ${ }^{144}$ Furthermore, the Codex Iustinianus indicates that in the third century the prefect exercised appellate jurisdiction in appeals against legal verdicts by (senatorial?) provincial governors. Severus Alexander decided that a governor could send accused men to his prefect Ulpianus for more severe punishment, while the emperor Gordianus confirmed that a man who was condemned by the governor could address the praetorian prefect for appeal. ${ }^{145}$ It is not known, however, under which emperor this practice started, nor whether anyone could approach a prefect for appeal directly or only through imperial delegation. Either way, the right of appeal did not mean that the prefect had authority over the governors.

A constitution from the reign of Maximinus Thrax determined that a forma which was issued by a prefect was to be considered binding as long as it did not contradict existing laws and constitutions. ${ }^{146}$ Although the exact significance of the constitution is unclear since the meaning of the word forma is disputed, it points at a further extension of the prefect's legal authority. ${ }^{147}$

The expansion of the praetorian prefects' authorities in the legal sphere coincides with the appointment of jurists and juridically skilled bureaucrats as prefects in the Severan era. ${ }^{148}$ Aemilius Papinianus belonged to

${ }^{143}$ In the early Principate prefects only had delegated jurisdiction, temporarily granted by the emperor. See Eich (2005), 217, note 1.

${ }^{144}$ Cf. Digesta 1, 11, 1, 1. Howe (1942), 35: 'In practice, however, appeals were granted by the emperors on rare occasions ... until Constantine finally settled the question by definitely forbidding them.' For the discussion on the possibility to appeal against decisions of the prefect, see Peachin (1996), 165-166.; 191-194; Eich (2005), 217, note 7, with further references.

145 Cod. Iust. 4, 65, 4, 1; 9, 2, 6. Cf. 8, 40, 13, in which Gordianus decided that a decurio should hand over a criminal to the governor or guard prefect.

146 Cod. Iust. 1, 26, 2: formam a praefecto praetorio datam, et si generalis sit, minime legibus vel constitutionibus contrariam, si nihil postea ex auctoritate mea innovatum est, servari aequum est. 'The rules promulgated by the praetorian prefect, even though they may be general in their character, must be observed, unless they contain something contrary to the laws or the constitutions, if they have not subsequently been annulled by my authority.', translation S.P. Scott (1973).

147 On the debate concerning the word forma, see Eich (2005), 219-221, with further references.

148 See De Blois (2001), 136-137, on the difficulty of distinguishing juridically skilled administrators or bureaucrats from learned jurists who carried out tasks in the public service. Cf. Salway (1997), 152-153. 
this category of men. As mentioned above, he had acted as advocatus fisci and a libellis before he became praetorian prefect in 205. According to Dio, Papinianus tried the case of robber Bulla Felix during his prefecture. ${ }^{149} \mathrm{He}$ was finally dismissed by Caracalla some time before the murder of Geta and killed not long thereafter in 212. ${ }^{150}$ A certain Patruinus murdered along with Papinianus at the request of the praetorians, was probably also praefectus praetorio at that time, and was likely identical with the jurist and procurator imperatoris Valerius Patruinus. ${ }^{151}$ Macrinus had followed a legal career as well: Dio records that he had become known to Plautianus through the successful advocacy of a friend's case, and that Plautianus made him his private advocate, probably as procurator managing part of his private domains. According to the Historia Augusta, Macrinus was then appointed advocatus fisci, a position responsible for looking after the interests of the imperial treasury. It may be conjectured that it was Plautianus who recommended him for the job. ${ }^{152}$ Fabius Cilo prevented Macrinus from being executed after Plautianus' downfall, although he was perhaps exiled for a while. ${ }^{153}$ Not long thereafter, however, Macrinus continued his career under Severus, became praefectus vehiculorum, procurator rationis and finally praefectus praetorio under Caracalla after Papinianus had been killed. ${ }^{154}$ Macrinus spent most of his career in the capital and it is very likely that he met Severus' elder son at some point in his career. Finally, Ulpianus was an apprentice of Papinianus and member of his consilium (as discussed in section

149 Dio $77,10,7$.

150 Dio 78, 1, 1; 4, 1; HA, Vita Sev. 21, 8; Vita Car. 4, 1-2; 8, 5-9.

151 Dio 78, 4, 1; HA, Vita Car. 4, 1-2.; Digesta 49, 14, 50. On Valerius Patruinus, see also Zwalve (2003).

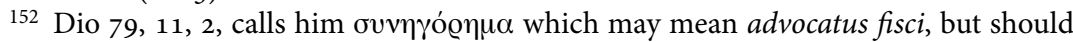
probably be regarded as private advocate here. See Liddell-Scott (1996), 1715, s.v. ouv-

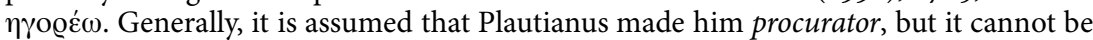
excluded that he held both positions, especially since HA, Vita Macr. 4, 4-6, reports that he was advocatus fisci.

153 The fact that Dio $(79,11,2)$ adds the words $\pi \alpha \varrho \alpha$ dó $\xi \alpha v$ ('beyond expectation') indicates that Macrinus was not regarded an amicus of Cilo. The exile is only mentioned in HA, Vita Macr. 4, 3 .

154 According to HA, Vita Diadum. 4, 1, Macrinus was procurator aerarii maioris by the birth of his son Diadumenianus in 208. Since this was the only record of this office, it has been suggested that this was an error and that the author meant to refer to Macrinus' post as procurator rationis/rei privatae, which is recorded elsewhere in the Historia Augusta (HA, Vita Macr. 2, 1); on this matter, see Pflaum (1960-1961), vol. 2, 670, no. 248. Dio $79,11,3$, also mentions several positions as procurator, but adds that Macrinus' held them under Caracalla. Pflaum (1960-1961), vol. 3, 1020, suggests that Macrinus may have held more than one procuratorship between 208 and 212. 
3.1), and may have been a libellis under Severus. By the end of 222, he was appointed praetorian prefect by Severus Alexander. ${ }^{155}$ Ulpianus is also attested as a member of the emperor's consilium, and in fact, several sources indicate that Ulpianus was an important adviser to the emperor, virtually co-regent. ${ }^{156}$ Although we are told that he was made prefect because he was an outstanding jurist, Ulpianus was not popular among the soldiers and is said to have needed special protection on occasion from the emperor. A conflict with the military in Rome led to his death in 223 or 224.157

Two other, less illustrious men can be added to the list of bureaucrats who were appointed praetorian prefect in the Severan era: Aurelius Iulianus, prefect under Severus, if he was indeed identical with the homonymous man who was a rationibus and a memoria; and a prefect under Elagabalus, ... atus, whose full name is unknown to us, who had been $a$ studiis prior to his prefecture. ${ }^{158}$ Whether the extension of the prefect's legal authority resulted from the appointments of great jurists and legally skilled bureaucrats from the late second century onward, or whether the expansion of the prefecture in the legal sphere attracted jurists to the position, is unclear. Since military skilled men were also appointed to the prefecture in the Severan period, as discussed above, legal knowledge can be excluded as a conditio sine qua non for an eques who pursued the praetorian prefecture in those days.

For the civil-administrative duties of the praetorian prefects evidence is scarce and less persuasive. Eich proffers an inscription from Saepinum dated in the reign of Marcus Aurelius as a clue for the praetorian prefect's role in the imperial civil administration. In it a rationibus Cosmus calls for the help of guard prefect Bassaeus Rufus concerning a dispute. It may have been an informal request for advice, as Rufus had been a rationibus himself and probably knew Cosmus; or Rufus may have been involved, since he had disciplinary authority in Italy. According to Eich, however,

155 Cod. Iust. 8, 37, 4; 4, 65, 4. According to HA, Vita Elag. 16, 5, Ulpianus was dismissed by Elagabalus, but it is unclear which position he held at that time and whether this statement is true. Aurelius Victor, Liber de Caesaribus 24, 6, seems to be mistaken when he reports that Elagabalus made Ulpianus praetorian prefect.

156 Dio 8o, 1, 1 (pp. 478-479); HA, Vita Sev. Alex. 26, 6; 31, 2; 68, 1. Cf. Cod. Iust. 4, 65, 4, 1 ('parentem meum'); 8, 37, 4 ('amici mei').

157 Oustanding jurist: Zosimus 1, 11, 2. Unpopular among praetorians: HA, Vita Sev. Alex. 51, 4. On his death: Dio 8o, 2, 2-4 (pp. 480-483).

158 For Aurelius Iulianus, see CIL 5.4323 = ILS 1333 (Brixia, Italy); 14.2463 (Castrimoenium, Italy). For $\ldots$ atus, see CIL 6.31776a $=A E 2003,182$ (Roma) and CIL 6.31776b = $A E$ 1997, 75 (Roma). See also Salway (1997). 
Cosmus addresses Rufus as though they both belonged to the imperial staff, and it should be read as an internal consultation. The praetorian prefect was of higher rank within the imperial staff and therefore had an executive role, perhaps coordinating the members of the staff, but Eich stresses that there is no indication either that the praetorian prefect had control over the a rationibus, nor that Cosmus was accountable to Rufus. ${ }^{159}$

Dio, through Maecenas, claims that the praetorian prefect should represent the emperor in supervising the caesariani, punishing the members of the administrative personnel at the imperial court and officials in the provinces who did not do their duty. Again, however, it is unclear whether Dio is here reflecting Severan reality or proposing for a reform. ${ }^{160}$ In the inscription from Aragua, mentioned in Chapter 1 (section 1.1), imperial coloni ask Philippus to end the violations of local potentes, administrators and soldiers marching by, and refer to a previous request for help during his prefecture. ${ }^{161}$ Still, it remains unclear whether they had approached him in his capacity as supervisor of the caesariani, or Gordianus had referred the coloni to his prefect. They may even have addressed Philippus just because he had been in the area at that time.

Owing to the growing number of military crises, the emperors required ever more resources. Therefore, the annona militaris, which was raised as a special tax presumably by Septimius Severus and paid in kind, gradually became the most important tax. In due course, the administration of the annona militaris was transferred to the praetorian prefects, who exercized got the final responsibility for the collection of this tax and had to coordinate provincial governors' tax collection. ${ }^{162}$ However, it is unclear when the praetorian prefect became involved with levying this tax, with most scholars nowadays positing a transfer after AD $284 \cdot{ }^{163}$

159 Eich (2005), 224-229 on CIL 9.2438 = AE 1983, 331 (Saepinum, Italy). Cf. Millar (1986), 312: 'The Praetorian Prefects, however, clearly could and did warn the local magistrates to desist from police activities which were damaging to the Imperial wealth'.

160 Dio 52, 24, 4. Ps.-Paulus, Sententiae 5, 17, 11, a source from the late third century, attests that the praetorian prefect at that point had the authority to punish the officiales of procurators. Eich (2005), 228: 'Diese officiales werden wohl ebenfalls als caesariani anzusehen sein.'

${ }^{161}$ CIL 3.14191 (Asia).

162 HA, Vita Av. Cass. 5, 8; Vita Gord. 28, 2; Vita Trig. Tyr. 18; Vita Prob. 10, 6-7; Zosimus 2, 32, 2.

163 In the past, scholars believed that the control over the military annona was transferred to the praetorian prefect under Severus. See Howe (1942), 29, note 28, with further references. Nowadays the more accepted view on this matter is that the annona probably 
Although the paucity of evidence precludes definite conclusions, there are indications that at certain moments in the third century some praetorian prefects saw their authority in the civil-administrative sphere somewhat increase. Yet the evidence is so scarce that it cannot be established whether this actually subordinated civil officials to the prefect. Furthermore, it is hard to determine whether this points to further formal and structural growth of the civil-administrative authorities of the praetorian prefect in the third century, or emperors used the prefects as civiladministration coordinators vice Caesaris only on an occasional, ad hoc basis. $^{164}$

To conclude, in the first decades of the period under discussion, under the Severan emperors, we can detect an expansion of the praetorian prefects' authority in the legal sphere. The praetorian prefects' jurisdiction within Italy had grown gradually as they became presidents of their own court of law in Rome, acting vice principis and being able to appeal against verdicts of provincial governors. Besides independent jurisdiction, from beyond the hundredth milestone from Rome, the praetorian prefects also were the highest-ranking military officers in Italy. The expansion of judicial authority obviously coincides with the prime of renowned jurists and legally skilled bureaucrats, but it cannot be determined whether their rise was the cause for the increasing legal responsibilities, or its consequence. In the Severan era, prefects continued to fulfill their basic task of protecting the imperial family and joining the emperors on military campaigns.

Yet, from about 240 onward, praetorian prefects increasingly received extraordinary commands, in which they had to solve military crises without the emperor's direct guidance. Such army commands were likely, at least initially, special delegations for particular campaigns. In this capacity, the praetorian prefect also acted vice Caesaris, being deployed when the emperor was not capable of solving a problem himself. The available evidence suggests that from the 240 os onward it was no longer standard to appoint two prefects. Although this had occurred occasionally before, it

remained a special tax until at least 284 and that the way it was collected was not standardized before the age of the Tetrarchy. See Jones (1964), vol. 1, 50; 449; Mitthof (2001); Eich (2005), 238, note 3, with further references. Carlà (2007), however, expresses a different view and argues the responsibility over the annona militaris was transferred to the praetorian prefect in the course of the second century.

${ }^{164}$ Cf. Eich (2005), 229-235. 
now seems to have become more common. Having two praetorian prefects had always acted as a mechanism for keeping the prefects' power in check. Perhaps the emperors realized that the prefect, as he had increasingly to act vice Caesaris, needed a higher level of autonomous power. Here too, however, it is difficult to distinguish cause from consequence. For now, the reason for the more frequent appointment of sole prefects remains obscure.

In the civil-administrative sphere, the prefect may have acted as the emperor's deputy occasionally as well, as there are indications-though scanty - that he at times had an executive role in the imperial staff.

Thus, the praetorian prefect's power gradually increased, as he operated ever more autonomously. In addition, the praetorian prefect functioned ever more as the emperor's personal assistant, or even his prime minister, who could represent the emperor when the latter was not willing or able to solve a situation himself. While the emperors' priorities changed, the scope of the praetorian prefect's power seems to have broadened, as he could be sent into action in any place where the emperor needed him. The praetorian prefect's power thus decreasingly required the emperor's vicinity. His power was second only to the emperor's. It cannot, however, be established whether the third-century expansion of the prefect's duties was formal and permanent, or the prefect continued to operate vice principis as a delegate of the emperor.

\section{The Status of the Praetorian Prefect}

By the end of the reign of Constantine, in $\mathrm{AD} 337$, the praetorian prefecture and the other high-ranking equestrian prefectures carried senatorial status. This section focuses on the process that led to this elevation of status. ${ }^{165}$

From viri eminentissimi to viri clarissimi: The Process of Honoring Praetorian Prefects

From the Augustan era, there was a tension between the actual power of the praetorian prefecture and the social status attached to the office. The equestrian status of the praetorian prefects guaranteed social inferi-

165 Over the last decades, several studies have examined the changing practices of honoring prefects from Septimius Severus to Constantine. See Pflaum (1970); Chastagnol (1988); Christol (1999); Benoist (2000). See most recently Salway (2006) with further references at p. 115 . 
ority to even the most junior members of the senatorial order. According to Salway, the negative example of Aelius Seianus reinforced the general principle that simultaneous performance of both a public magistracy like a consulate and service in one of the great equestrian prefectures was incompatible. ${ }^{166}$ Seianus, originally appointed co-prefect with his father by Tiberius in AD 14, became sole prefect when his father was sent off to govern Egypt. Seianus was granted ornamenta praetoria (the insignia of the the praetorship). After Tiberius' retreat to Capri, Seianus stayed behind in Rome and effectively acted as the emperor's viceroy. In January 31, Seianus was consul ordinarius with the emperor Tiberius as his colleague, all the while continuing in his post as praetorian prefect. Eventually, of course, Tiberius disposed of Seianus: persuaded that his prefect now threatened his own imperial position, the emperor executed him. The well-known example of Seianus illustrates the danger of allowing a prefect to combine the social prestige of senatorial status with the power and influence of the praetorian prefecture. During the remainder of the first century $\mathrm{AD}$, tenure of the prefecture became considered incompatible with membership of the senate. Serving prefects could still be awarded senatorial ornamenta, but the established sociopolitical hierarchy required an equestrian prefect to retire from his post before embarking on a senatorial cursus honorum. In this way, praetorian prefects held inferior social rank, whatever actual power they exercised. ${ }^{167}$

In the second century, the Antonine emperors rewarded some praetorian prefects with ornamenta consularia (the insignia of the consulship) while still in office. These emperors furthermore allowed prefects who had received these senatorial ornamenta to replace the epithet eminentissimus with the senatorial title clarissimus. ${ }^{168}$ The grant of senatorial ornamenta only permitted the holder the symbols and titles of a senator, but not full membership in the order. Thus, the longstanding principle that entry into the senate was incompatible with simultaneous exercise of the praetorian prefecture preserved the social distinction between the senatorial and equestrian orders established in the Iulio-Claudian period.

\footnotetext{
166 Salway (2006), 117-118.

167 Salway (2006) 118-119, for examples of equestrian prefects who were granted senatorial ornamenta. Salway also points out (119) that under the Flavians a couple of men became praetorian prefects, who were already senators at the time of their appointments, namely the future emperor Titus and his brother-in-law Arrecinus Clemens.

168 See Salway (2006), 119, note 21, for examples.
} 
Under Septimius Severus, the praetorian prefect Fulvius Plautianus managed to obtain a position comparable to that of Seianus. ${ }^{169}$ Closely associated with the emperor through their common origin in Lepcis Magna and an alleged familial relationship, Plautianus was praefectus vigilum before he was promoted to the praetorian prefecture. ${ }^{170}$ As praetorian prefect, he was granted ornamenta consularia in 197, and probably became sole prefect after the death of his colleague Aemilius Saturninus circa 200. ${ }^{171}$ Two years later, he further enhanced his position by attaching himself to the imperial family through the marriage of his daughter Plautilla to Caracalla. Thereupon, Plautianus was treated as a full member of the domus divina in public dedications. In 203, when he obtained an ordinary consulship, Plautianus officially became a senator, and his family was even enrolled as patrician. ${ }^{172}$ The consular pair of 203 was presented as C. Fulvius Plautianus II P. Septimius Geta II, treating Plautianus' prior consular ornamenta as equivalent to a genuine previous tenure of the magistracy and relegating Severus' brother's name to the second position. No doubt Severus offended the senatorial order by doing all this. Plautianus' consulate was contrary to the usual practice: while his consulship made Plautianus a full member of the senate, he continued to serve as prefect until his death. A Roman inscription even accidentally honors him as fourth emperor, alongside Severus, Caracalla and Geta. ${ }^{173}$ It may be assumed that the statue incident discussed above took place at about the same time. ${ }^{174}$ As said above, a final split between the emperor and Plautianus in January 205 ended in the prefect's death. His memory was damned and custom restored, as Herodianus emphasized, when two praetorian prefects replaced him. ${ }^{175}$

Caracalla did not honor a prefect in office with membership in the senate, but he clearly promoted two ex-equestrians, holders of consular ornamenta, to ordinary consulships that were considered iterations. One of them, Maecius Laetus, consul 'II' in 215, had been praetorian prefect under Severus; the other, Messius Extricatus, is attested as praefectus

\footnotetext{
169 Dio 58, 14, 1, explicitly compares Plautianus to Seianus.

${ }^{170}$ Herodianus 3, 10, 6. Severus and Plautianus were probably related through Severus' mother Fulvia Pia. See Birley (1988), 221, no. 32.

${ }^{171}$ In CIL 6.224 (Roma, June AD 197) Plautianus is attested as vir clarissimus. Howe (1942), 70-71, assumes there were successors of Saturninus as colleagues of Plautianus.

172 CIL 6.226 (Roma, AD 202); CIL 11.8050 = ILS 9003 (Tuficum, Italy).

${ }^{173}$ CIL 6.227 = ILS 427 (Roma).

174 Dio 76, 16, 2; HA, Vita Sev. 14, 5-6.

175 Herodianus 3, 13, 1. On Plautianus' damnatio memoriae, see Varner (2004), 161164 with further references.
} 
annonae in 210, was perhaps praetorian prefect under Caracalla, and became consul 'II' in 217. ${ }^{176}$ Caracalla's grant of ornamenta consularia to his praetorian prefects Oclatinius Adventus and Macrinus conformed to Antonine practice. Macrinus seems to have attempted to prevent his ornamenta from being included in the count for his consulship in 218, because he did not want to offend senators any further. ${ }^{177}$ Under Elagabalus, however, the practice of counting consular ornamenta as genuine tenures continued: the emperor apparently allowed Comazon his iteration. Thereafter, however, there are no unambiguously attested examples of the practice. ${ }^{178}$ Neither Caracalla nor Elagabalus appointed serving equestrian prefects into senatorial offices. ${ }^{179}$

Just as the Historia Augusta's testimony that Elagabalus enrolled people into the senate without distinction as to age, status or type finds little confirmation, ${ }^{180}$ so its statement of Severus Alexander's policy with regard to his praetorian prefects is doubtful as well:

His prefects of the guard he would promote to the rank of senator in order that they might belong to the class of The Illustrious (Lat: clarissimi) and be so addressed. Previous to his time such promotions had been made rarely, or, if made at all, had been of short duration [...] Alexander, however, in wishing the prefects to be senators had this end in view, namely, that no one might pass judgment on a Roman senator who was not a senator himself. ${ }^{181}$

It suggests that Severus Alexander introduced a policy of making his praetorian prefects senators. The account, however, wrongly supposes

176 See Salway (1997), 148-153, for a reconstruction of the careers of Laetus $\left(P I R^{2}\right.$ M 54) and Extricatus (PIR ${ }^{2}$ M 518). Laetus succeeded Plautianus as prefect in 205. The exact year of his replacement is unclear, but he certainly was no longer a praetorian prefect at the time of his consulship in 215. In inscriptions, Laetus preceded his colleague M. Munatius Sulla Cerialis ( $A E$ 1984, 178, Italy: 'Maecio Laeto II et Sulla Ceriale cos'; $A E$ 1959, $308=A E$ 2003, 1512 (Italy) and $A E$ 1998, 1618: 'Laeto II et Ceriale cos.'), whereas Extricatus ceded precedence to the younger patrician senator C. Bruttius Praesens (CIL 6.1984 = ILS 5025 (Roma): 'C. Bruttio Praesente, T. Messio Extricato II cos.') Cf. Salway (2006), 124.

177 Dio 79, 13, 1-2, praises him for the attempt.

178 Salway (2006), 127, note 63, argues that prior ornamenta are improbable for M. Aurelius Carus, consul II in 283, and C. Valerius Diocletianus, consul II in 285. It is more likely that these iterations arose from suffect consulships on their elevations to the throne in 282 and 284. See Rémy (1976-1977), 175-176; Chastagnol (1992), 228-229.

179 As said, Laetus and Extricatus had both retired from equestrian service before their consulships, and Comazon combined the praetorian prefecture with the ornamenta consularia and his senatorial consulship with the urban prefecture in 220.

${ }^{180}$ HA, Vita Elag. 6, 2.

${ }^{181}$ HA, Vita Sev. Alex. 21, 3-5. On this passage, see Chastagnol (1970). 
that praetorian prefects had only rarely been clarissimi before the reign of Severus Alexander and falsely equates senatorial ornamenta with full membership of the senate. Although some have appealed to the Album of Canusium to support the notion that Alexander gave his prefects senatorial dignity on their appointment, Nicols' view of the document, that the praetorian prefects played an important role as patroni in Italy and were therefore listed as men of senatorial rank, provides a plausible alternative explanation for this abnormality. ${ }^{182}$ In fact no source from Severus Alexander's reign equates prior ornamenta with a properly held consulship.

All known praetorian prefects from Alexander's later years up to Gallienus' sole reign were eminentissimi. There is no evidence that any praetorian prefect received ornamenta or senatorial membership through appointment as consul. Since the mounting tension between senators and equites manifested itself in the senatorial revolt of 238 , it is no surprise that the emperors hesitated to grant their praetorian prefects senatorial status between the late 230 and the 260 . Perhaps the prefects themselves also avoided the impression that they wanted to share in the traditional senatorial prestige for a while. By no means, however, did this signal political weakness: Timesitheus, for instance, was just as powerful as Plautianus had been, and perhaps even more powerful, since his sonin-law the teenage emperor Gordianus III must have been more compliant than the mature Septimius Severus. Yet Timesitheus remained an eques. ${ }^{183}$ The same applies to Priscus: while even after his brother Philippus had replaced Gordianus as emperor in 244, Priscus continued in office as praefectus praetorio, while de facto ruling the Eastern part of the Empire, nonetheless, as far as we know, he never became a vir clarissimus. ${ }^{184}$ Praetorian prefects' complete avoidance of senatorial honors, even those who were very closely connected to the imperial throne, may not only have been a consequence of the events in 238: it may also indicate a certain devaluation of senatorial status in this period.

Unfortunately, the 250 s present a lacuna in information on praetorian prefects and their status. ${ }^{185}$ The first known case in which a serving prefect was granted senatorial honors again can be found during Gallienus'

182 Nicols (1988), 126, suggests that those men appear in the Album as clarissimi viri because they had been awarded senatorial ornamenta.

${ }^{183}$ CIL $6.1611=31831$ (Roma, undated) credits Timesitheus as eminentissimus vir.

184 Priscus as vir eminentissimus: CIL 3.14149, $05=$ ILS 9005 (Arabia, 246).

185 Salway (2006), 128, points out that the appointments of Ulpius Silvinus and Porcius Aelianus, both eminentissimi, may have belonged to this decade. 
sole reign. By then, the prevailing tendency to avoid senatorial honors for prefects in office seems to have come to an end. In 261, Gallienus shared the ordinary consulship with his praetorian prefect Petronius Taurus Volusianus. ${ }^{186}$ Obviously, Volusianus ceded precedence to the emperor in the proclamation of the consuls, so precedence was not an issue. Neither was the pseudo-iteration, since the practice of granting ornamenta consularia had by then apparently ceased to exist. Like Comazon, Volusianus switched to the senatorial cursus honorum: he became urban prefect in 267-268. However, Heraclianus, the only other known praetorian prefect of Gallienus, did not become consul and thus remained an eminentissimus vir, so apparently Gallienus did not grant his prefects senatorial honors as a matter of general policy. ${ }^{187}$

Aurelianus also appointed a serving praetorian prefect to an ordinary consulship: Iulius Placidianus in 273. In an inscription from Gallia Narbonensis, Placidianus is attested as praetorian prefect and vir clarissimus. ${ }^{188}$ There appears to be no warrant for positing prior ornamenta, as there is no evidence for iteration. Yet, the order in which the consuls were proclaimed, with the patrician senator preceding the senior equestrian official (Tacitus et Placidianus cos.), shows that senatorial sensibilities were taken into consideration. ${ }^{189}$ Thus, from 260 onward, a new practice emerged: praetorian prefects were nominated directly to the consulship and this appointment became their entry to senatorial status. ${ }^{190}$ These prefect-consuls retained their offices as consulars. This situation exhibited more clarity than the Severan practice of a genuine consulship following consular ornamenta, and it may have actually reaffirmed the value of senatorial dignity for the effective political potentes.

Under Diocletian, the situation showed no drastic change. Before 284, more than one consular ex-prefect had already reached the urban prefecture (i.e. Comazon, Volusianus). During the reign of Diocletian some consular ex-prefects became not only urban prefects, but also proconsuls of Africa or Asia, which in fact reaffirmed the superior social prestige of

\footnotetext{
186 CIL $11.5749=$ ILS 7221 = AE 1992, 562 (Sentinum, Italy); HA, Vita Gall. 1, 2.

$187 A E$ 1948, 55 (Thracia).

${ }^{188}$ CIL 12.1551 (Gallia Narbonensis).

189 According to Christol (1986), 111-113; 153-158, the consul Tacitus is to be identified with A. Caecina Tacitus.

190 This new practice also applied to other high equestrian prefects: in 275, Iulius Marcellinus, prefect of Egypt in 271, prefect of Mesopotamia and rector Orientis in 272, was appointed consul ordinarius with the emperor Aurelianus as his colleague. See $P I R^{2}$ A 1546; I 403; PLRE I, Marcellinus 1; 2; 19; 20; 21; Christol (1986), 113-114. Cf. Salway (2000), 129 .
} 
these high senatorial positions. Eventually, the upper stages of the senatorial and equestrian careers converged during the reign of Constantine, as he granted the title vir clarissimus and thus senatorial dignity to all praetorian prefects and some other high equestrian prefects. ${ }^{191}$

\section{Some Implications: Praetorian Prefects and Senators in the Imperial Service}

In 203, when Septimius Severus appointed Plautianus consul during his prefecture, thereby granting him entry into the senate, this decision encountered opposition from one faction in the palace, including Caracalla and Iulia Domna. It is hardly surprising that the majority of Severus' entourage, which included a considerable number of senators, was not amused. The actual power and influence of a praetorian prefect had always depended on the personality of both him and his emperor, but until then the prefect's social inferiority to the traditional senatorial aristocracy had restricted it. ${ }^{192}$ The resistance against Plautianus' growing power doubtlessly derived from his overwhelming power and his senatorial status in an era in which senators still dominated both the imperial entourage and the essential military and administrative posts. That explains why the later emperors of the Severan era were much more cautious in granting their prefects senatorial status.

At the end of the 230 s and in the 240s, neither senatorial ornamenta nor full membership in the senate through consulates were assigned to the praetorian prefects, definitely in reaction to the events in 238 . Yet by the 260 , the tide had turned, for by then, as discussed in the previous chapter, the senators tended to focus on Italy, Africa and Asia, as the main areas where they exercised power. Great military commands went into equestrian rather than senatorial hands, which had largely reduced the military influence of the senators in the imperial service, as will be further discussed in Chapter 4. It was in those days also that the practice of nominating sitting prefects as consul was re-established. It is noteworthy that by then the authority of praetorian prefects, certainly in the military and legal sphere, had also increased in comparison with the end of the second century AD.

191 On the period AD 284-337, see also Chastagnol (1970), 52-59; Salway (2006), 128133.

192 The only exception to this rule was Seianus, whose position has been discussed above. 
Senatorial status will not have added much to the authority of the praetorian prefect in his contacts with military commanders: the military cadre basically consisted of equites and the praetorian prefect had since long been the highest-ranking equestrian official. Yet, in his relation with the senators senatorial status and even actual membership of the senate may have expanded the praetorian prefect's authority. At the same time when the prefect's jurisdiction within Italy had been extended, the civiladministrative role of senators within Italy had increased, as senators were acting as correctores and curatores within communities. Viewed from that perspective, senatorial status for a praetorian prefect who operated within Italy may have been desirable. Volusianus' promotion to senatorial rank, for instance, may have been intended as a way to increase his authority over senators in Rome and Italy. If Volusianus acted as counterpart to the senatorial men in Italy, who will have attached great importance to senatorial status and who had become acquainted with him as an equestrian vir militaris when he commanded Roman cohorts in the 250s, an elevation of Volusianus' status would have lent him the necessary authority to control senators in the imperial service serving in Italy. Seen from that point of view, the remark of the Historia Augusta that Severus Alexander gave his praetorian prefects senatorial rank (senatoria dignitas) lest no Roman senator would be judged by someone who was not a senator ('ne quis non senator de Romano senator iudicaret'), may have been nearer to the truth than initially thought and generally assumed by most scholars, although the imperial policy was clearly dated too early in the third century and ascribed to the wrong emperor. ${ }^{193}$

This situation was not necessarily restricted to Italy. As discussed above, the praetorian prefect could appeal the verdict of a provincial governor at least from the reign of Gordianus III onward. In practice, this implied that the jurisdiction of senatorial governors was open to challenge from the praetorian prefect, a man who had great power, but was of inferior social status. ${ }^{194}$ It must have been hard for the senators to accept this situation, especially for the senatorial elite discussed in Chapter 2. The fact, however, that the praetorian prefect acted vice principis, as delegate of the emperor, may have mitigated senators' loss of power and sense of degradation. By 260 , the process of replacing senatorial

${ }^{193}$ HA, Vita Sev. Alex. 21, 3-5.

${ }^{194}$ In the late 230 and early 240 , senatorial governors had not yet been replaced as regularly with equestrian agentes vice praesidis or praesides as from the 260 onward. 
members of the imperial staff by equestrian men was in an advanced stage. Yet, Gallienus still chose to grant Volusianus both senatorial rank and actual entry into the senate. As noted above, this may have enabled the praetorian prefect to stand up against the senatorial elite in Italy, and perhaps even ended the need for imperial delegation. If so, this step simplified the process. While Gallienus was busy solving military crises, there was no need for him to delegate judicial and perhaps even civiladministrative tasks to his praetorian prefect who was active in Italy: the elevation of rank enabled the prefect to act on his own authority. Although by 260 , the time may have been ripe for this move, this remains merely a conjecture for the moment, and we must note that the occasional status elevation of praetorian prefects may still have appeared to contemporaries to be a reward or a consequence of their increased authority, preventing the occurrence of status dissonance. ${ }^{195}$

The careful process by which the third-century emperors gradually elevated the status of the praetorian prefects toward senatorial dignity makes clear that, although the social structure in the Empire had by then become less rigid, the rulers still had to be cautious not to offend the senatorial aristocracy with too progressive reforms. It was not until Constantine, about half a century after the reign of Gallienus, senatorial status was granted to all the praetorian prefects and other high equestrians. ${ }^{196}$

\section{Praetorian Prefects and Emperors}

The growing power and status of the praetorian prefect in the course of the third century coincided with shifts in the social and career background of the Augusti who ruled the Empire between 193 and 284 and their priorities. As has been discussed in Chapter 1, emperors were prevalently senatorial until the reign of Gallienus. Macrinus, Maximinus Thrax and Philippus Arabs were the only emperors before 268 who clearly had equestrian status at the time of their proclamation. Both Macrinus

195 Cf. Peachin (1996), 161: '[...] the practice of appointing substitutes had, by the early third century, already long existed. However, we find, beginning with the Severans, a seemingly greater frequency of the practice, and this was accompanied by a tendency to allow people of lesser or, in Roman terms, a more inappropriate status to function thus.' The necessity of imperial delegation as the basis of the praetorian prefect's authority has socio-political implications that I intend to examine in greater depth in future research.

196 Cf. Eich (2005), 239-241, who, with the example of Africa, demonstrates that even in the fourth century emperors avoided offending the traditional aristocracy by depriving them of traditional offices in favor of equestrian officials. 
and Philippus were praetorian prefects when they were acclaimed. Most emperors who reigned between 268 and 284, on the other hand, had equestrian status when they were proclaimed. This indicates that senatorial status gradually faded as an essential factor for acclamation as emperor. An important step in the process of granting sitting prefects senatorial dignity can be traced under Gallienus' sole emperorship as well. This implies that senatorial status no longer served to distinguish an emperor from praetorian prefect(s). A few emperors had had praetorian prefects of equal social ranks in the first half of the third century, but this equality became more or less continuous by the 260 . This may explain why praetorian prefects did not automatically receive senatorial rank between 268 and 284. All the emperors in this period, however, assumed senatorial rank soon after their acclamation and held ordinary consulships to affirm their membership of the senate, which reflects the value still attached to senatorial status, at least in certain circles. Thus, the distinction in social status between the praetorian prefect and the emperor appears to have been marginal in the last decades of the period under scrutiny. ${ }^{197}$

As for praetorian prefects' power, the available evidence displays an increasing focus on legal and bureaucratic duties in the age of the Severi, followed by a period in which the praetorian prefect appears primarily in military contexts. ${ }^{198}$ It is notable that the pre-imperial careers of both Septimius Severus and Macrinus were juridically and bureaucratically oriented. The other emperors of the Severan era owed their acclamation to dynastic connections; they were proclaimed at a young age before being eligible to hold any positions. In those first decades of the third century, several praetorian prefects were lawyers or juridically skilled bureaucrats. In contemporary literary evidence legal expertise constituted practically the ideal talent for a prefect. In 235, Maximinus Thrax was the first emperor, as far as we know, whose previous career consisted solely of military positions, and he is the first of a series of thirdcentury emperors whose military skills and experience are emphasized

\footnotetext{
197 I hope to return to the reasons for and consequences of the shift of the praetorian prefects' power and status in a later publication.

${ }^{198}$ Again, this conclusion might be biased by the surviving evidence. However, it is striking that people with very clear expertise in legal matters could rise to the praetorian prefecture under the Severi and that later praetorian prefects mainly used their military expertise. This obviously leaves open the possibility that these military prefects also interfered in legal and bureaucratic matters, but it was clearly no longer their main area of expertise. Cf. Honoré (1994); De Blois (2001).
} 
in the available evidence. Admittedly, the cause of the shift may lie in the fact that the sources on the second half of the third century tend to stress military experience. Yet it is striking that the same increasing focus, first on legal and bureaucratic authorities, later on military authority, can be traced if we examine the power exercised by the third-century praetorian prefects.

From circa 240 onward, the emperors' priorities changed drastically and they no longer seem to have been able to divide their attention between military, civil-administrative, diplomatic and legal matters. Ever more occupied with waging war and solving problems in border regions, emperors increasingly assigned praetorian prefects to carry out duties which had previously been reserved for the emperor. As ever before during the Principate, it is complicated to determine whether tasks were added to the range of individual prefects' duties, or the responsibilities of the praetorian prefecture as an office were extended, which would imply that when a task was assigned to one prefect, it automatically belonged to the job responsibilities of the next. Here, we run into the same obstacle that we face with regard to emperorship: the position was never constitutionally specified. This prevents us from establishing whether the prefect should be regarded a magistrate with imperium acting on his own authority, or whether he always acted vice Caesaris, based on special delegation by the emperor which was only temporarily legitimate. Although some developments indicate an increase of personal authority, as demonstrated above, the evidence offers no clear answer to this question: the exact legal status of the prefect cannot be established. What can be established, however, is that the changes in the position of the praetorian prefect mirrored changes in the background and priorities of the emperors, and that in the second half of the third century prefects increasingly operated separately from the emperor and the imperial entourage, as they mainly solved military crises.

From the reign of Philippus, long-term habitation in the capital was no longer an option for emperors. Military crises in various parts of the Empire forced emperors to focus on either the East or the West, and to either disregard the problems in other parts of the Empire or to send a trustworthy deputy to resolve critical situations. In the latter case, emperors obviously preferred to send a relative or, if no family member was available, a praetorian prefect as his deputy. Philippus sent Priscus, who conveniently was both a relative and his praetorian prefect, to the East while he himself concentrated on the war against the Carpi and Germanic tribes. Volusianus covered Italy while Gallienus fought against 
the Goths and Heruli in the Balkans. Aurelianus had Placidianus fight in Gallia Narbonensis while he himself was in the East.

As in earlier periods of the Principate, third-century emperors regularly chose relatives as prefects, if they were available. The reason for this practice was evident: a relative was naturally bound to the emperor and thus considered a loyal ally. Occasionally, however, it happened the other way around: a prefect could be brought into the imperial family. The implications of prefects' entry into the imperial family are less evident than the practice of appointing a relative as praetorian prefect. It may have expressed the emperor's trust of the prefect or secured loyalty. Perhaps the intention was to elevate a prefect's status without actually granting him senatorial status. A prefect who was allied to the imperial family would certainly be more acceptable to senators as an emperor's deputy.

In sum, third-century developments in emperorship and the prefecture were strongly connected and interdependent. As in previous centuries, the power and status of the praetorian prefect in the third century largely depended on the nature and authority of the emperor he served. Yet, while Seianus under Tiberius, and both Perennis and Cleander under Commodus, mainly profited from their rulers' lack of interest in governance-if we may believe the literary evidence-the praetorian prefects of the third-century owed their expanding positions to external factors which occupied emperors and undermined their authority increasingly. ${ }^{199}$ It was probably due to these circumstances that prefects assumed ever more imperial tasks, first mainly in the legal and bureaucratic sphere, and later also in military crises. Gradually, the prefect's authority was extended. Whether he continued to operate vice principis, as imperial delegate, or whether his power developed toward a personal authority (imperium) would be interesting information to have. Unfortunately, however, as so often with third-century material, the available evidence does not enable us to draw conclusions on this matter. It does seem clear that ultimately, the prefect was the second most important man of the Empire, whose social status was second only to the emperor-and even the emperor could not always outdo him.

\footnotetext{
199 On Seianus under Tiberius, see Hennig (1975); Levick (1976). On Perennis and Cleander under Commodus, see Hekster (2002), 60-77.
} 


\subsection{Conclusion}

As was noted at the beginning of this chapter, the ordo equester was an even more heterogeneous group than the ordo senatorius. Focusing on those equestrians at the very top of Roman imperial administration who saw their power increase, two main trends can be detected. One already started well before the period under discussion: intellectuals from the Greek and Latin world replaced imperial freedmen as imperial secretaries. Under the Severan emperors, sophists and jurists still played an important role at court. They had a relatively high status within the ordo. As imperial secretaries they held the title virperfectissimus, and they often attained the highest equestrian prefectures or could even gain admission into the senate. Their rhetorical and intellectual qualities, which their high status generally allowed them to develop, made them exceptionally qualified candidates to perform secretarial duties for the emperor. In other words, taking the perspective of Dahl's power aspect, we may say that the power of this group of equites seems to have been based primarily on their education, i.e. their paideia, and their scholarly reputation. Civiladministrative, financial and legal responsibilities fell within the scope of their power. In that respect, their role was comparable to that of the senatorial elite discussed in Chapter 2. However, whereas the senatorial elite may have profited from the shift of priorities from the center to the periphery and the emperor's increasing absence from Rome, equestrian intellectuals' power depended mostly on the emperor's vicinity at court and his concern with non-military matters. Consequently, from the 230 , when the emperors were forced increasingly to focus on military crises in border regions, this group of equestrians seems to have reduced its active, or at least its perceptible, involvement in imperial administration, even in cases of intellectuals who accompanied the emperor on his campaigns.

From the reign of Septimius Severus onward, equestrians were also increasingly appointed as provincial governors and military commanders. This second trend was of a different order, as in this case it was no longer imperial liberti whose previous posts equestrians now filled, but senators. This extension of equestrian power, however, was often disguised as a provisional appointment: many equestrians were appointed as agens vice, and thus supposedly replacing senators temporarily as deputies. A great number of these positions went to ranking soldiers who had eventually acquired equestrian status. Whereas this group only constituted a minority within the ordo equester in the first and most of the second centuries $\mathrm{AD}$, in the course of the third century military profes- 
sionals came to dominate within the equestrian order. The military crises under Marcus Aurelius, during which militarily skilled equestrians such as Pertinax were able to rise rapidly, can probably count as the situation where this trend first developed. From the 230 on onward, emperors badly needed such professional military men. Their military experience was the main reason that they could participate in imperial power and thus their main power base. The power of those men who rose to the top of imperial administration depended furthermore on access to money and supplies and the support of a great number of soldiers. Considering the other aspects of power as defined by Dahl, military matters dominated the scope of their power, and those subject to their power consisted solely of the soldiers under their command. For duces, a geographic area ( $d u x$ limitis or dux ripae) or specific army units (dux exercitus) often constituted the domain of their authority. How much power they could exercise varied and depended on a combination of factors, such as the number of troops they commanded, the presence and level of authority of other (military) power holders in the area, and the resources at their disposal.

The office of the praefectus praetorio, the high equestrian position on which we are best informed, experienced a similarly gradual extension of power over the course of the third century. The available evidence demonstrates an increasing focus first on legal and bureaucratic authority at the beginning of the period under scrutiny and later, from circa 240 onward, a focus on military authority. Thus, the development of the range of duties assigned to the highest ranking equestrian seems to reflect the main development within the ordo: the high status of the educated intellectuals, sophists and jurists, who dominated at court from the late second century until the 23 os was gradually assumed by military professionals. It is noteworthy that a similar process occurred in the emperorship, as has been demonstrated in Chapter 1. That emperors who spent most of their time at court in Rome selected a different type of men as praetorian prefect than emperors who were mostly active in military campaigns at the peripheries is only logical, as emperors' shifting priorities demanded different qualities in their second man. Ideally, a praetorian prefect combined legal, civil-administrative and military skills, as all these matters fell within the scope of the prefect's power. Sometimes, the simultaneous appointment of two praetorian prefects with a different background could mobilize a combination of these skills. However, the appointment of two simultaneously operating praetorian prefects, which was a simple way to control the level of power either of them could exercise, seems to 
have passed out of use over the course of the third century. This obviously allotted a (single) praetorian prefect more power. As to the domain of the praetorian prefect's power: he was second only to the emperor and thus the second most powerful man within the Empire. Eventually, the praetorian prefect's status was equalized to his high level of power: prefects received senatorial rank and titulature, and could even enter the senate as consuls, while retaining their office as prefect. From the 260 s such a status upgrade was occasionally applied. Consequently, those praetorian prefects may have approached (but not equaled) the status of the senatorial elite, who by then seem to have dominated areas such as for instance Italy as curatores and correctores. Combined with the replacement of senators by equestrians in the military sphere, this elevation of status may have contributed to the praetorian prefect's increasing ability to operate autonomously, separate from the emperor. Whether the praetorian prefect continued to operate on the basis of imperium delegated by the emperor, or his imperium was eventually attached to the prefecture itself, is unresolved. Either way, this will have affected the power which the prefect could exercise, especially in confrontations with men of high status. Yet, as said above, for now this matter remains unresolved.

Since the status elevation of the praetorian prefect, the highest equestrian officer, rose in the third century, it would be reasonable to conjecture that the military professionals who came to dominate the ordo equester experienced a comparable upgrade in status in due course. In fact, there are some indications that a growing number of equestrian officers received the title vir perfectissimus. Whereas this title had been reserved for high-ranking equestrian prefects and imperial secretariesequestrian men with a relatively high level of paideia and status-, up until the Severan era, from the 240 on onward the title was also bestowed upon less high-ranking equestrian officers. It is notable that this elevation in status started long after equestrians had been assuming positions which were previously reserved for senators. The lack of clarity caused by the fact that such appointments were initially presented as interim solutions may have facilitated this lag time.

These examples of status elevation within the equestrian order may indicate that senatorial status became somewhat less prestigious in the course of the third century. Both the equestrian emperors and the fact that men like Timesitheus and Priscus, who played essential roles within imperial administration, seem not to have been elevated to senatorial rank support this proposition. The same applies to the inscription concerning Rufinus, in which his equestrian status is recorded well before his 
consular rank. Yet, it should be noted that the increase of status within the equestrian order was not ubiquitous: individual equestrians saw their level of status rise, but not all members of the ordo experienced such elevation of status. Likewise, senatorial status was not subject to a certain depreciation everywhere in the Empire, as has been discussed in Chapter 2. Moreover, the fact that some high equestrian prefects were granted senatorial dignities may also indicate that senatorial status was still the highest status symbol available, at least in those areas where senators still played an active role in imperial administration.

To conclude, the changing position of equestrians who served at the very top of Roman imperial administration shows close connections with the changing composition of the order in the period under discussion. Categorical statements as they have been made by scholars in the past are therefore indemonstrable. 